\title{
Overview of receptor-based source apportionment studies for speciated atmospheric mercury
}

\author{
I. Cheng ${ }^{1}, X . X^{2}$, and L. Zhang ${ }^{1}$ \\ ${ }^{1}$ Air Quality Research Division, Science and Technology Branch, Environment Canada, 4905 Dufferin Street, Toronto, \\ Ontario, M3H 5T4, Canada \\ ${ }^{2}$ Department of Civil and Environmental Engineering, University of Windsor, 401 Sunset Avenue, Windsor, Ontario, \\ N9B 3P4, Canada
}

Correspondence to: L. Zhang (leiming.zhang@ec.gc.ca)

Received: 27 January 2015 - Published in Atmos. Chem. Phys. Discuss.: 25 February 2015

Revised: 24 June 2015 - Accepted: 7 July 2015 - Published: 17 July 2015

\begin{abstract}
Receptor-based source apportionment studies of speciated atmospheric mercury are not only concerned with source contributions but also with the influence of transport, transformation, and deposition processes on speciated atmospheric mercury concentrations at receptor locations. Previous studies applied multivariate receptor models including principal components analysis and positive matrix factorization, and back trajectory receptor models including potential source contribution function, gridded frequency distributions, and concentration-back trajectory models. Combustion sources (e.g., coal combustion, biomass burning, and vehicular, industrial and waste incineration emissions), crustal/soil dust, and chemical and physical processes, such as gaseous elemental mercury (GEM) oxidation reactions, boundary layer mixing, and GEM flux from surfaces were inferred from the multivariate studies, which were predominantly conducted at receptor sites in Canada and the US. Back trajectory receptor models revealed potential impacts of large industrial areas such as the Ohio River valley in the US and throughout China, metal smelters, mercury evasion from the ocean and the Great Lakes, and free troposphere transport on receptor measurements.

Input data and model parameters specific to atmospheric mercury receptor models are summarized and model strengths and weaknesses are also discussed. Multivariate models are suitable for receptor locations with intensive air monitoring because they require long-term collocated and simultaneous measurements of speciated atmospheric $\mathrm{Hg}$ and ancillary pollutants. The multivariate models provide more insight about the types of $\mathrm{Hg}$ emission sources and $\mathrm{Hg}$ pro-
\end{abstract}

cesses that could affect speciated atmospheric $\mathrm{Hg}$ at a receptor location, whereas back trajectory receptor models are mainly ideal for identifying potential regional $\mathrm{Hg}$ source locations impacting elevated $\mathrm{Hg}$ concentrations. Interpretation of the multivariate model output to sources can be subjective and challenging when speciated atmospheric $\mathrm{Hg}$ is not correlated with ancillary pollutants and when source emissions profiles and knowledge of $\mathrm{Hg}$ chemistry are incomplete. The majority of back trajectory receptor models have not accounted for $\mathrm{Hg}$ transformation and deposition processes and could not distinguish between upwind and downwind sources effectively. Ensemble trajectories should be generated to take into account the trajectory uncertainties where possible. One area of improvement that applies to all the receptor models reviewed in this study is the greater focus on evaluating the accuracy of the models at identifying potential speciated atmospheric mercury sources, source locations, and chemical and physical processes in the atmosphere. In addition to receptor model improvements, the data quality of speciated atmospheric $\mathrm{Hg}$ plays an equally important part in producing accurate receptor model results.

\section{Introduction}

Gaseous elemental mercury (GEM), gaseous oxidized mercury (GOM), and particle-bound mercury (PBM) are the three forms of mercury that are found in the atmosphere. GEM is the most abundant form of $\mathrm{Hg}$ in the atmosphere comprising of at least $90 \%$ of the total atmospheric $\mathrm{Hg}$. 
GOM and PBM are $\mathrm{Hg}^{2+}$ compounds that are operationally defined because their exact chemical compositions are not known (Gustin et al., 2015). The different chemical and physical properties of speciated atmospheric $\mathrm{Hg}$ influence emission, transport, conversion, and deposition processes. Sources emit different proportions of GEM, GOM, and PBM. GEM has an atmospheric residence time of 6 months to 1 year and is thus capable of long-range transport, whereas GOM and PBM have residence times of a few weeks, which limits them to local or regional transport (Lynam and Keeler, 2005). Speciated atmospheric $\mathrm{Hg}$ can convert between the different forms by oxidation and reduction reactions and gasparticle partitioning processes (Subir et al., 2012). All forms of $\mathrm{Hg}$ can undergo dry deposition; however, wet deposition is more likely to occur for GOM and PBM because of the higher water solubility of $\mathrm{Hg}^{2+}$ (Schroeder and Munthe, 1998). Consequently, GOM and PBM are easily transported from the atmosphere to land and water where they are eventually converted to methylmercury, which is the most toxic form of $\mathrm{Hg}$ to wildlife and humans.

The emission, transport, and transformation processes of speciated atmospheric $\mathrm{Hg}$ are examined in detail in sourcereceptor relationship studies. One type of study is chemical transport modeling, which predicts speciated atmospheric $\mathrm{Hg}$ concentrations on regional and global scales based on the knowledge of source emissions, atmospheric dispersion and transport, and chemical and physical atmospheric processes. However, there are still many uncertainties about mercury behavior in the real atmosphere that have yet to be addressed (Travnikov et al., 2010; Subir et al., 2012). An alternative approach to studying source-receptor relationships is receptorbased methods. In this type of study, receptor measurements (e.g., air concentrations, precipitation concentrations, or wet deposition) and back trajectory modeling are used separately and together to predict pollution sources and estimate the contributions of the sources to receptor measurements (Belis et al., 2013). Receptor-based methods do not require comprehensive knowledge of source emissions and mercury behavior in the atmosphere; therefore, they are less complicated than chemical transport models.

Receptor models have been applied in source apportionment studies of particulate matter, volatile organic compounds, and speciated atmospheric $\mathrm{Hg}$. There are numerous reviews on receptor models in general (Hopke, 2003, 2008; Hopke and Cohen, 2011) and reviews specific to particulate matter source apportionment (Viana et al., 2008a; Watson et al., 2008; Chen et al., 2011; Pant and Harrison, 2012; Belis et al., 2013), the positive matrix factorization receptor model (Reff et al., 2007), and back trajectory statistical models (Kabashnikov et al., 2011). The information provided in past review papers provide background knowledge into the various receptor models and discussion of the model advantages and disadvantages based on particulate matter source apportionment findings; however, it might not be highly relevant to speciated atmospheric mercury. This paper provides a review of the major receptor-based methods used in the source apportionment of speciated atmospheric mercury, including a summary of the input data and model parameters used in receptor modeling of speciated atmospheric mercury and findings that may advance our understanding of mercury behavior in the atmosphere. The review is focused on five major receptor-based methodologies: principal components analysis, positive matrix factorization, potential source contribution function, gridded frequency distribution, and concentration-back trajectory models.

\section{Overview of receptor-based methodology}

\subsection{Multivariate models}

\subsubsection{Principal components analysis (PCA) description}

Most data sets have atmospheric $\mathrm{Hg}$ and other environmental parameters which could be other air pollutants and/or meteorological conditions, since atmospheric processes, such as transport and diel patterns, are controlled by meteorological parameters. PCA is a data reduction method available in many statistical software packages. The large number of parameters observed at the receptor site are reduced to a smaller set of components or factors that explain as much of the variance in the data set as possible (Thurston and Spengler, 1985). This is based on the following mathematical model:

$Z_{i j}=\sum_{k=1}^{P} S_{i k} L_{k j}$.

$Z_{i j}$ is the standardized observed concentration of the $j$ th pollutant in the $i$ th sample; $S_{i k}$ is the $k$ th component score on the $i$ th sample; $L_{k j}$ is the component loading for each pollutant; $k$ is the component; $P$ is the number of components, which represent pollution sources. The input variables in the data set should have some correlations; however, the model components should be independent from each other. There are several statistics that have been determined to assess whether the data set is suitable for PCA, such as the Kaiser-MeyerOlkin measure of sampling adequacy ( $>0.6$ criterion) and Bartlett's test of sphericity ( $p<0.05$ criterion). The number of components to retain is determined by other statistics such as Kaiser's criterion (eigenvalues $>1$ ), scree plot, analysis of variance, and/or parallel analysis, as well as by achieving some minimal value of percent variance of the data set explained by all the components (e.g., 70-80\%) and how easily the components can be interpreted (Blanchard et al., 2002; Lynam and Keeler, 2006; Temme et al., 2007; Cheng et al., 2009). The number of components in a suitable solution to Eq. (1) should be less than the number of variables. Typically, in PCA studies for atmospheric $\mathrm{Hg}$, two to six components have been selected to explain the majority of the variance in the data set. Varimax rotation is normally applied to 
the components in the final PCA solution so that they can be more easily interpreted (Thurston and Spengler, 1985).

The varimax-rotated components are assigned to mercury sources by examining the component loadings of the chemical species markers, meteorological parameters, and $\mathrm{Hg}$. The component loadings from PCA may be positive or negative; the sign is indicative of the association between the component and a particular parameter. Large component loadings between a component and an air pollutant marker indicate that the pollutant is a major component of that factor, e.g., coal-combustion factor with a large positive loading on $\mathrm{Hg}$. Variables with component loadings greater than 0.3 or 0.5 are typically used to assign the model components to sources. Source emissions profiles for $\mathrm{Hg}$ sources are available from receptor-based source apportionment literature as well as from databases, such as the US EPA (Environmental Protection Agency) SPECIATE (USEPA, 2014a), to assign PCA model components to emission sources. Various chemical species and air pollutants are markers or signatures of specific source types. Elemental carbon is emitted from primary combustion sources; higher organic carbon to elemental carbon ratios and presence of $\mathrm{Ba}, \mathrm{Ca}, \mathrm{Na}, \mathrm{Pb}, \mathrm{CO}$, and $\mathrm{NO}_{x}$ are indicative of motor vehicle emissions and vehiclerelated dust; $\mathrm{C}^{13} / \mathrm{C}^{14}$ carbon isotopes are related to biogenic sources; $\mathrm{Se}$ and $\mathrm{SO}_{2}$ are representative of coal-fired power plants; $\mathrm{Ni}$ and $\mathrm{V}$ are emitted from oil combustion; $\mathrm{Ca}$ and $\mathrm{Fe}$ are related to cement kilns; $\mathrm{Zn}, \mathrm{Pb}, \mathrm{Cu}$, and $\mathrm{Cl}$ are indicative of municipal waste incineration; $\mathrm{V}, \mathrm{Cr}, \mathrm{Mn}$, and $\mathrm{Fe}$ are emitted from steel production; $\mathrm{K}$, organic carbon, and levoglucosan are markers associated with biomass burning; $\mathrm{Si}, \mathrm{Ca}, \mathrm{Al}$, and $\mathrm{Fe}$ could represent soil and crustal sources; $\mathrm{Na}$ and $\mathrm{Cl}$ are the major components of sea-salt aerosols (Keeler et al., 2006; Lynam and Keeler, 2006; Lee and Hopke, 2006; Watson et al., 2008; Zhang et al., 2008, and references therein). Due to resource limitations, only 3 of 22 PCA studies reviewed have particulate matter composition data available. Other air pollutant data utilized in the remaining studies ranked by high to low frequency are $\mathrm{SO}_{2}$, $\mathrm{O}_{3}, \mathrm{NO}, \mathrm{CO}, \mathrm{PM}_{2.5}, \mathrm{NO}_{2}, \mathrm{NO}_{x}, \mathrm{PM}_{10}, \mathrm{BC}, \mathrm{NMHC}, \mathrm{THC}$, $\mathrm{CH}_{4}, \mathrm{HNO}_{3}$, TSP, VOC, $\mathrm{NH}_{3}$, and TRS.

Although it is a statistical model, PCA has been applied in numerous air quality studies especially for the source apportionment of particulate matter; thus, it is based on wellestablished principles, e.g., conservation of mass and mass balance analysis (Hopke, 2003; Hopke et al., 2005). PCA can be readily accessed from commercial statistical software in which the detailed procedures of performing PCA are also widely available. Unlike source-based chemical transport models, PCA does not require detailed data on source emissions profiles, chemical reaction kinetics and physical processes, and meteorological forecasts (Hopke, 2003). The major disadvantage of PCA is that the interpretation of the components can be subjective when there are insufficient chemical species markers in the data set (Viana et al., 2008b). As a result, the chemical profiles of the components are not unique. PCA results identify major components but could not quantify contributions of each component to receptor concentrations; however, this can be achieved by determining the absolute principle component scores (APCS) (Thurston and Spengler, 1985). Unlike the positive matrix factorization model discussed in Sect. 2.1.2, PCA does not consider the data quality of the variables (e.g., outliers, below detection limit data), which may lead to inaccurate model results (Hopke and Cohen, 2011).

\subsubsection{Positive matrix factorization (PMF) model description}

The PMF model (Paatero and Tapper, 1994; USEPA, 2014b) is accessible from the US EPA website. The principle behind PMF is that every concentration is determined by source profiles and source contributions to every sample. The model equation is given by Eq. (2):

$x_{i j}=\sum_{k=1}^{P} g_{i k} f_{k j}+e_{i j}$.

$x_{i j}$ is the concentration of the $j$ th pollutant at the receptor site in the $i$ th sample; $g_{i k}$ is the contribution of the $k$ th factor on the $i$ th sample; $f_{k j}$ is the mass fraction of the $j$ th pollutant in the $k$ th factor; $P$ is the number of factors, which represent pollution sources; $e_{i j}$ is the residual for each measurement or model error (difference between observed and modeled concentrations).

PMF has numerous applications in the source apportionment of particulate matter (Lee and Hopke, 2006; Lee et al., 2008; Viana et al., 2008b; Tauler et al., 2009) and volatile organic compounds (Song et al., 2008). Similar to PCA, the PMF model is used when sources are unknown since it does not require the input of source profile data. However, knowledge of potential sources is necessary to interpret model results (Watson et al., 2008). PMF is ideal for a data set with a large number of samples (e.g., > 100, Watson et al., 2008). For atmospheric $\mathrm{Hg}$ source apportionment, the input variables have included speciated atmospheric Hg (GEM, GOM, $\mathrm{PBM})$, trace gases $\left(\mathrm{CO}, \mathrm{NO}_{x}, \mathrm{O}_{3}, \mathrm{SO}_{2}\right)$, trace metals, $\mathrm{PM}_{2.5}$, particle number concentrations, and/or carbon (black carbon, Delta-C) measured at the receptor site (Liu et al., 2003; Cheng et al., 2009; Wang et al., 2013). Delta-C is the difference in black carbon measured at two wavelengths, 370 and $880 \mathrm{~nm}$, which is indicative of wood combustion (Wang et al., 2013). Reff et al. (2007) provides the key points to consider for inputting data into the PMF model. The PMF model also requires a data set of uncertainties corresponding to the receptor measurements or estimated from equations, which are used to assess the variables and/or samples that should be down-weighted or excluded from the model (Reff et al., 2007; USEPA, 2014b). Other input requirements include the number of runs, starting seed, and number of factors to compute. The model determines the optimal non-negative factor 
contributions and factor profiles by minimizing an objective function, which is the sum of the square difference between the measured and modeled concentrations weighted by the concentration uncertainties (Liu et al., 2003; Reff et al., 2007; Watson et al., 2008; USEPA, 2014b). The objective function, $Q$, is determined by Eq. (3):

$Q=\sum_{i=1}^{n} \sum_{j=1}^{m}\left[\frac{x_{i j}-\sum_{k=1}^{P} g_{i k} f_{k j}}{s_{i j}}\right]^{2}$.

$x_{i j}$ is the ambient concentration of the $j$ th pollutant in the $i$ th sample; $g_{i k}$ is the contribution of the $k$ th factor on the $i$ th sample; $f_{k j}$ is the mass fraction of the $j$ th pollutant in the $k$ th factor; $s_{i j}$ is the uncertainty of the $j$ th pollutant on the $i$ th measurement; $P$ is the number of factors, which represent pollution sources; $m$ and $n$ denote the total number of pollutants and samples, respectively.

Multiple runs of the PMF model are performed to determine the optimal number of factors. In speciated atmospheric $\mathrm{Hg}$ studies, the model fit and uncertainties were assessed by analyzing the standardized residuals to ensure they were randomly distributed and within 2 or 3 standard deviations and/or performing regression analysis between modeled and observed concentrations. The factor profiles in the final solution are assigned to sources using source emissions profiles for $\mathrm{Hg}$ sources available from receptor-based source apportionment literature and from databases, such as US EPA SPECIATE, similar to PCA.

In general, the strengths of the PMF model are similar to those of PCA described in the previous section. However, the major advantage of PMF over PCA is the inclusion of measurement uncertainties in the PMF model, which ensures measurements with large uncertainties have less influence on the model results. This feature is particularly important for receptor-based source apportionment of speciated atmospheric Hg because GOM and PBM measurements have large uncertainties. Comparison of data between various mercury instruments indicated that GOM concentrations may be underestimated by a factor of 1.6-12 depending on the chemical composition of GOM (Gustin et al., 2015). The extent of the GOM measurement uncertainties have not been widely accepted by the scientific community based on online peerreview discussions of this study; however, research on this important issue is progressing. For PBM measurements, it is unclear whether they are underestimated or overestimated and how large the uncertainties are (Gustin et al., 2015). The factor profiles from the PMF model may be more easily interpreted than the component loadings from PCA because the factor profiles from PMF are in the same units as the input concentrations. A potential disadvantage with the PMF model, similar to PCA, is that the procedure of assigning components to sources can be subjective when there are insufficient chemical species markers in the data set. This leads to issues with collinearity of factor profiles (Watson et al., 2008; Chen et al., 2011). Ancillary chemical species marker measurements may not always be collocated with speciated atmospheric $\mathrm{Hg}$ measurements. Refer to Table 1 for a comparison between PCA and PMF models.

\subsection{Back trajectory receptor models}

Back trajectory receptor models simulate the movement of air parcels from the receptor site, which represents the potential pathway for transporting air pollutants from sources to the receptor site. Back trajectories are often included in source apportionment studies to supplement the multivariate models previously described because the simulated airflows incorporate meteorological data (Hopke and Cohen, 2011). The HYSPLIT (Hybrid Single Particle Lagrangian Integrated Trajectory) model (Draxler and Rolph, 2014; Rolph, 2014) has often been used in atmospheric mercury source-receptor studies (Han et al., 2004, 2005; Lynam and Keeler, 2005; Liu et al., 2007; Rutter et al., 2007; Abbott et al., 2008; Choi et al., 2008; Li et al., 2008; Lyman and Gustin, 2008; Sprovieri and Pirrone, 2008; Cheng et al., 2009; Peterson et al., 2009; Sigler et al., 2009; Kolker et al., 2010). The HYSPLIT model simulates the transport of an air parcel by wind and estimates the position of the parcel using velocity vectors that have been spatially and temporally interpolated onto a grid (Han et al., 2005). The inputs to the HYSPLIT model include the number of trajectory start locations, type of trajectory, location of the receptor site, and meteorological data source (Draxler and Rolph, 2014; Rolph, 2014). The model parameters selected by the user are the type of model to simulate vertical motion, starting time and height of the trajectories, total duration of the trajectories, and number of trajectories. The input data and model parameters for back trajectory simulations depend on the sampling location and the back trajectory receptor model selected as discussed below. The output from back trajectory models includes the hourly locations of the trajectory segment endpoints, altitude, and other meteorological variables along the trajectory.

\subsubsection{Potential source contribution function (PSCF) description}

PSCF is the probability that a source area contributes to elevated pollutant concentrations, as defined by a concentration threshold, at the receptor site. Airflows are simulated using back trajectory models. PSCF is mathematically expressed as the ratio of the total number of trajectory segment endpoints in a grid cell $(i, j)$ that is above a concentration threshold $\left(m_{i j}\right)$ to the total number of trajectory segment endpoints in a grid cell $(i, j)$ over the entire sampling period $\left(n_{i j}\right)$ as shown in Eq. (4) (Hopke, 2003; Watson et al., 2008). $W_{i j}$ is a weighting function used to adjust for a small number of trajectory endpoints in grid cell $(i, j)$. Grid cells are color coded based on the PSCF value and are plotted on a map to high- 


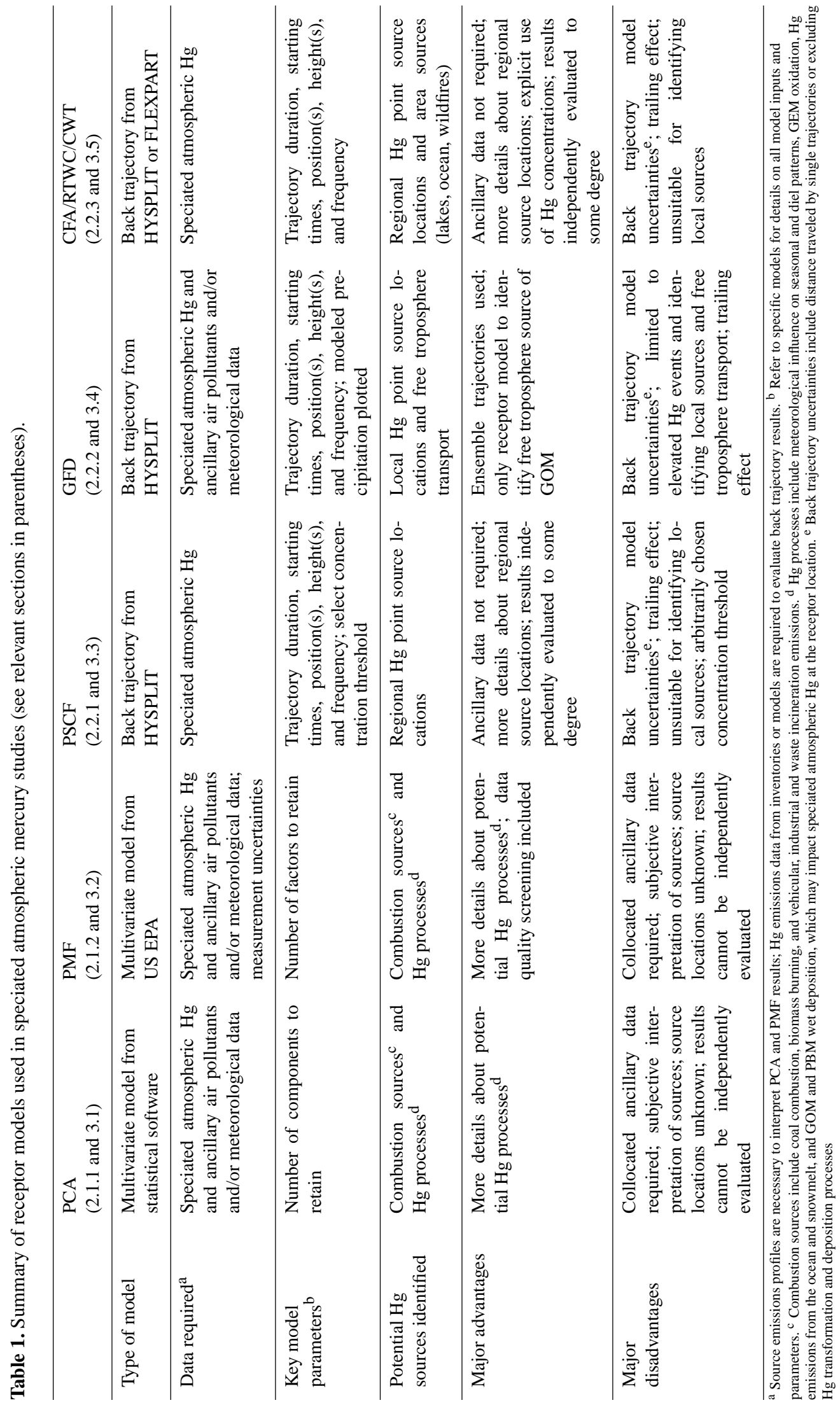


light potential sources areas affecting the receptor measurements. Areas with high PSCF values (approaching 1) have a higher probability of airflows contributing to elevated atmospheric $\mathrm{Hg}$ concentrations at the receptor site.

$\operatorname{PSCF}_{i j}=\frac{m_{i j}}{n_{i j}} W_{i j}$

The mean atmospheric $\mathrm{Hg}$ concentration over the entire sampling period and/or particular season is the threshold selected for $m_{i j}$ in many PSCF studies for speciated atmospheric $\mathrm{Hg}$ (Han et al., 2005, 2007; Choi et al., 2008; Xu and Akhtar, 2010; Fu et al., 2011, 2012a, b). Other studies have used the 75th percentile concentration as the concentration threshold (Lee et al., 2014) or determined a suitable threshold from short-term elevated GEM events (Abbott et al., 2008). A map of the model domain is typically divided into grid cell sizes of $1^{\circ} \times 1^{\circ}$ (Han et al., 2005; Choi et al., 2008; Xu and Akhtar, 2010); however, a finer grid has also been applied, e.g., $0.5^{\circ} \times 0.5^{\circ}, 0.25^{\circ} \times 0.25^{\circ}$, or $0.2^{\circ} \times 0.3^{\circ}$ (Abbott et al., 2008; Fu et al., 2011, 2012a, b; Lee et al., 2014). In general, the size of the grid cells depend on the study area considered (Hopke, 2003).

To determine PSCF, a large number of back trajectories were generated using the HYSPLIT model. PSCF studies of speciated atmospheric $\mathrm{Hg}$ used archived meteorological data sets available in the HYSPLIT model, such as EDAS (Eta Data Assimilation System) for North American locations (Han et al., 2005, 2007; Abbott et al., 2008; Choi et al., 2008; Xu and Akhtar, 2010) and GDAS (Global Data Assimilation System) for sites in China (Fu et al., 2011, 2012a, b) and Korea (Lee et al., 2014). The back trajectory duration selected in most PSCF studies ranged from 72 to $120 \mathrm{~h}$ for GEM and TGM (Choi et al., 2008; Xu and Akhtar, 2010; Fu et al., 2012a, b), whereas Abbott et al. (2008) generated $24 \mathrm{~h}$ trajectories. A $48 \mathrm{~h}$ trajectory duration was typically chosen for GOM and PBM (Han et al., 2005; Choi et al., 2008) because of their shorter atmospheric residence time compared to GEM. Since the daily mean speciated atmospheric $\mathrm{Hg}$ concentration was used to determine PSCF values, trajectories were generated at intervals of $24 \mathrm{~h}(\mathrm{Xu}$ and Akhtar, 2010; Fu et al., 2012a) or $6 \mathrm{~h}$ (Han et al., 2005, 2007) to represent the airflows for a sampling day. For $7.5 \mathrm{~h}$ GOM and $3.5 \mathrm{~h}$ PBM samples, Fu et al. (2012a) generated back trajectories at intervals of 8 and $4 \mathrm{~h}$, respectively. Most studies computed back trajectories at a single start height representative of the mixing height of the boundary layer, such as 100 or $500 \mathrm{~m}$ above model ground level, whereas Fu et al. $(2011,2012 a$, b) determined back trajectories at multiple starting heights (e.g., $500,1000,1500 \mathrm{~m})$.

After determining the number of trajectory segment endpoints in each grid cell, a weighting factor was typically applied to PSCF values in some studies if the number of the endpoints in a grid cell was less than 2 or 3 times the average number of endpoints in all the grid cells (Han et al., 2005, 2007; Xu and Akhtar, 2010; Fu et al., 2011, 2012a, b;
Lee et al., 2014). In one study, grid cells with less than four trajectory segment endpoints were omitted from the PSCF calculation (Abbott et al., 2008).

The advantage of PSCF over the multivariate receptor models is that it provides the spatial distribution of potential source areas contributing to the receptor site. With PSCF, regional anthropogenic point sources can be identified if the locations of $\mathrm{Hg}$ point sources are plotted together with the PSCF results. In contrast, multivariate models infer potential types of sources but do not provide information about where the $\mathrm{Hg}$ sources are located. PSCF also does not require ancillary pollutant measurements. This data may not be available at the receptor location, and the sampling resolution may not be the same as the speciated atmospheric $\mathrm{Hg}$ data, which require additional data processing. The disadvantages with PSCF are related to back trajectory modeling of speciated atmospheric $\mathrm{Hg}$ since the models may not simulate chemical reactions, gas-particle partitioning processes, and $\mathrm{Hg}$ deposition. There are also uncertainties with the distance traveled by single back trajectories (Stohl, 1998; Watson et al., 2008). Due to the back trajectory model resolution, PSCF is not ideal for identifying potential local sources. In addition to disadvantages of trajectory models, the majority of the trajectory segment endpoints are found near the receptor location where all the back trajectories converge (Watson et al., 2008). The larger $n_{i j}$ affects the PSCF calculation in Eq. (4) because it results in a larger denominator and may lead to a lower PSCF value. This also depends on the concentration threshold selected because a smaller threshold likely produces higher PSCF values.

\subsubsection{Gridded frequency distributions (GFD) description}

GFD is another back trajectory receptor model that has been applied to speciated atmospheric Hg and GOM dry deposition data (Weiss-Penzias et al., 2009, 2011; Gustin et al., 2012). The model domain is divided into $1^{\circ} \times 1^{\circ}$ grid cells. GFD involves calculating the average number of trajectory segment endpoints in each grid cell based on an ensemble of trajectories generated using the HYSPLIT model. The average number of trajectory points in all the grid cells is plotted on a map to show the spatial distribution of the average trajectory residence time. The trajectory ensemble consists of multiple trajectory starting locations and heights. There are nine starting locations evenly spaced in a $0.5^{\circ} \times 0.5^{\circ}$ grid cell. The receptor site is located in the center of the grid cell with the eight other starting locations surrounding the receptor site. Three or four starting heights ranging from 100 to $2000 \mathrm{~m}$ above model ground level were selected in previous GFD studies. The higher starting altitudes were chosen because the studies were interested in large-scale atmospheric patterns (e.g., transport from free troposphere). The back trajectory duration ranged from 72 to $120 \mathrm{~h}$ and was generated every 3-6h. 
GFD has only been applied to data subsets, such as elevated or enhanced speciated atmospheric $\mathrm{Hg}$ events. In Weiss-Penzias et al. (2009), the enhancement event was defined by the simultaneous occurrence of GOM concentrations at $>75$ th percentile of the daily mean at three nearby receptor locations. In another study, GFD was determined for GOM enhancement events in which at least one concentration exceeded the 98th percentile (Weiss-Penzias et al., 2011). The length of a GOM enhancement event was determined by measurements above the mean concentration. The events were further stratified into data subsets impacted by local sources and free troposphere transport. The first data subset was derived by analyzing the frequency distributions of GOM / $\mathrm{SO}_{2}$ ratios. The second data subset had GOM concentrations similar to the first data subset, but $\mathrm{SO}_{2}$ concentrations were much lower (Weiss-Penzias et al., 2011). A similar approach for defining GOM enhancement events was also adopted by Gustin et al. (2012). The data subset used to generate the GFD was limited to a specific range of wind directions in order to verify the sources of GOM enhancement events were due to several local electricity power plants (Gustin et al., 2012).

The advantage of GFD over other back trajectory receptor models is the generation of trajectories at multiple starting locations and heights. Ensemble trajectories illustrate the variability in the pollutant transport pathways, which indicates how uncertain a single trajectory can be (Stohl, 1998; Hegarty et al., 2009; Gustin et al., 2012). Some of the disadvantages of PSCF also apply to GFD, such as back trajectory uncertainties and higher number of trajectory endpoints approaching the receptor location discussed in Sect. 2.2.1. The GFD model was applied to only small data subsets that met a specific criteria and therefore excluded a large proportion of the entire data set. Classification of the data subsets also requires knowledge about the sources contributing to elevated pollutant concentrations at the receptor site.

\subsubsection{Concentration field analysis (CFA), residence time weighted concentration (RTWC), concentration-weighted trajectory (CWT) description}

CFA, RTWC, and CWT are also common back trajectory receptor models that have been used to identify potential source areas contributing to speciated atmospheric $\mathrm{Hg}$ measurements (Han et al., 2007; Rutter et al., 2009; de Foy et al., 2012; Cheng et al., 2013b). The most apparent difference between CFA/RTWC/CWT and previously described back trajectory receptor models is that the trajectory residence time in the grid cells have been weighted by the observed atmospheric $\mathrm{Hg}$ concentrations corresponding to the arrival of each trajectory. CFA, RTWC, and CWT can be summarized by Eq. (5) (Kabashnikov et al., 2011):
$P_{i j}=\frac{\sum_{l=1}^{L} c_{l} \tau_{i j l}}{\sum_{l=1}^{L} \tau_{i j l}}$.

$P_{i j}$ represents the source intensity of a grid cell $(i, j)$ contributing to the receptor location. $c_{l}$ is the speciated atmospheric $\mathrm{Hg}$ concentration corresponding to the arrival of back trajectory $l$ in the CWT model. For CFA or RTWC, logarithmic concentrations are used. $\tau_{i j l}$ is the number of trajectory segment endpoints in grid cell $(i, j)$ for back trajectory $l$ divided by the total number of trajectory segment endpoints for back trajectory $l$ (i.e., residence time of a trajectory in each grid cell); $L$ is the total number of back trajectories over a time period (e.g., entire sampling period or a season) (Cheng et al., 2013b). As the model equation shows, higher atmospheric $\mathrm{Hg}$ concentrations would lead to higher source intensity if the trajectory residence time were the same. In CFA, RTWC, and CWT, the trajectory residence time scaled by the observed concentration is also normalized by the trajectory residence time.

The FLEXPART-WRF (FLEXible PARTicle-Weather Research and Forecasting) model simulates the transport and dispersion of air pollutants (Stohl et al., 2005; Fast and Easter, 2006). In CFA studies for speciated atmospheric $\mathrm{Hg}$, FLEXPART-WRF simulated the path of 100-1000 particles released from the receptor location (Rutter et al., 2009; de Foy et al., 2012). The particles were tracked for $48 \mathrm{~h}$ in Rutter et al. (2009), since CFA was applied to speciated atmospheric $\mathrm{Hg}$ data. Six-day trajectories were determined by de Foy et al. (2012) to simulate the transport of GEM. The hourly locations of the particles are counted in all the grid cells that have been overlaid on a map of the study area. The HYSPLIT back trajectory model using the EDAS $40 \mathrm{~km}$ archived meteorological data was used in the CWT studies for speciated atmospheric $\mathrm{Hg}$ (Cheng et al., 2013b). Back trajectories of $48 \mathrm{~h}$ were generated for each $3 \mathrm{~h}$ GEM, GOM, and PBM concentration at a single start height representative of the coastal location. The hourly locations or trajectory segment endpoints for every trajectory are tallied for all grid cells. CWT was determined for grid cells with at least two sets of $c_{l}$ and $\tau_{i j l}$.

As summarized in Table 1, the advantage of CFA and CWT over PSCF and GFD described in previous sections is the integration of the receptor concentrations in the back trajectory model as evident in Eq. (5). This is important because the observed concentrations account for the various physical and chemical processes as an air pollutant is transported from sources to the receptor site (Jeong et al., 2011). PSCF uses a concentration threshold to determine the trajectory residence time associated with elevated $\mathrm{Hg}$ concentrations; however, it may be perceived as arbitrary. Consequently, the receptor measurements that are slightly below the threshold con- 
centration are excluded from PSCF calculation (Han et al., 2007). Another advantage of CFA and CWT is that the source intensity of the grid cells is normalized by the trajectory residence time, which reduces the bias due to increasing trajectory residence time near the receptor location. In the CFA studies for speciated atmospheric $\mathrm{Hg}$, the use of a particle dispersion trajectory model is more suitable for simulating turbulent flows and has been validated by tracer experiments (Hegarty et al., 2013). The disadvantages of CFA and CWT are the uncertainties associated with back trajectory modeling, especially when single trajectories are generated (Stohl, 1998). Common to many of the back trajectory receptor models described in this section and previously, the potential $\mathrm{Hg}$ source areas identified by the models are not often evaluated against $\mathrm{Hg}$ emissions inventory quantitatively, which makes it difficult to determine the accuracy of the models at reconstructing the sources (Kabashnikov et al., 2011). This evaluation requires a comprehensive $\mathrm{Hg}$ emissions inventory because both anthropogenic and natural sources contribute significantly to global Hg emissions (Pirrone et al., 2010).

\section{Overview of existing studies}

\subsection{PCA results}

\subsubsection{Source apportionment}

PCA has been used to apportion potential sources affecting TGM and speciated atmospheric Hg in Seoul, South Korea (Kim and Kim, 2001; Kim et al., 2011); Changbai Mountain (Wan et al., 2009a, b) and Xiamen (Xu et al., 2015), China; Göteberg, Sweden (Li et al., 2008); Poland (Majewski et al., 2013); Canada; and the US. The Canadian sites are located in Point Petre and Egbert, Ontario (Blanchard et al., 2002); CAMNet stations (Temme et al., 2007), Toronto (Cheng et al., 2009), northwestern Ontario (Cheng et al., 2012); Kejimkujik National Park (Cheng et al., 2013a); Flin Flon, Manitoba (Eckley et al., 2013); Fort McMurray, Alberta (Parsons et al., 2013); and Windsor, Ontario (Xu et al., 2014). The US sites included south Florida (Graney et al., 2004); Detroit, Michigan (Lynam and Keeler, 2006; Liu et al., 2007); Mount Bachelor, Oregon (Swartzendruber et al., 2006); Athens, Ohio (Gao, 2007); Rochester, New York (Huang et al., 2010); and Grand Bay, Mississippi (Ren et al., 2014). Most of the studies identified a factor/component that was representative of combustion sources (e.g., coal combustion, vehicular, industrial, biomass burning, and waste incineration emissions) regardless of whether the studies were conducted in urban, rural, or coastal locations. This component generally consisted of high component loadings on $\mathrm{Hg}$ and other air pollutant markers, such as $\mathrm{NO}_{x}, \mathrm{SO}_{2}, \mathrm{O}_{3}$, $\mathrm{PM}_{2.5}$, black carbon, $\mathrm{CO}$, and/or trace metals. A component consisting of GEM, $\mathrm{NO}_{x}$, and $\mathrm{CO}$ was attributed to vehicular emissions in Detroit (Lynam and Keeler, 2006). Graney et al. (2004) was able to narrow down the PBM source in south Florida to waste incineration because of the presence of PBM, V and Ni in one of the components. Higher loadings for TGM, $\mathrm{Ag}, \mathrm{Cd}, \mathrm{Cr}, \mathrm{Mn}, \mathrm{Mo}, \mathrm{Se}, \mathrm{Sn}$ and $\mathrm{Zn}$ at a rural location in Point Petre were assigned to distant anthropogenic/coal combustion sources (Blanchard et al., 2002). The presence of $\mathrm{NO}_{x}, \mathrm{SO}_{2}$ and $\mathrm{PM}_{2.5}$ in a component was assigned to marine transportation after verifying that the back trajectories passed over shipping ports along the US east coast (Cheng et al., 2013a). The percent variance that can be explained by anthropogenic combustion sources varied from 10 to $57 \%$ among the studies reviewed. It explained most of the variance (>35\%) at some urban locations, such as in Seoul, Toronto, Windsor, and south Florida because of the proximity to $\mathrm{Hg}$ point sources and/or traffic (Kim and Kim, 2001; Graney et al., 2004; Cheng et al., 2009; Xu et al., 2014). At rural locations further away from $\mathrm{Hg}$ point sources and traffic, $15-29 \%$ of the variance was explained by the transport of anthropogenic combustion emissions (Blanchard et al., 2002; Cheng et al., 2012, 2013a). The PCA studies of atmospheric $\mathrm{Hg}$ also attributed the sources of TGM and PBM at rural sites to crustal sources (Blanchard et al., 2002; Graney et al., 2004; Cheng et al., 2012, 2013a). This component typically included TGM or PBM and $\mathrm{Si}, \mathrm{Al}, \mathrm{Fe}, \mathrm{Mn}, \mathrm{Sr}$, $\mathrm{Ti}, \mathrm{Ca}^{2+}, \mathrm{Mg}^{2+}$, and/or $\mathrm{K}^{+}$and explained between 12 and $41 \%$ of the variance in the data set.

Aside from emission sources, many of the PCA studies derived components from the data sets that are representative of atmospheric chemical and physical processes. These processes can also influence atmospheric $\mathrm{Hg}$ concentrations at a receptor location. In many instances, local meteorology, GEM oxidation, diurnal mixing, and snow melting were the major components affecting atmospheric $\mathrm{Hg}$ at the receptor sites, rather than anthropogenic combustion sources. The most often used meteorological parameters are relative humidity, temperature, and wind speed, which are easy to obtain or readily available from weather stations, followed by pressure, solar radiation, and ultraviolet radiation. Kim and Kim (2001) assigned a component to meteorological influence based on the presence of TGM, temperature and $\mathrm{O}_{3}$. Liu et al. (2007) also found positive loadings on GEM, water vapor mixing ratio and $\mathrm{O}_{3}$, and negative loadings on PBM and wind speed for the component representing seasonal meteorology. Surface GEM emissions of previously deposited $\mathrm{Hg}$ were recognized as a major TGM source in Flin Flon, Manitoba, after the closure of Canada's largest Hg point source (Eckley et al., 2013). This result was inferred from an increase in TGM loading on the meteorology component that consists of temperature, solar radiation and relative humidity, and a decrease in TGM loading on the component representing the smelter after it was shutdown. TGM measurements at a site in the Alberta oil sands region was mainly attributed to diurnal variability based on strong component loadings on $\mathrm{O}_{3}$ and meteorological parameters including, temperature, relative humidity, and solar radiation (Parsons et al., 2013). 
GEM oxidation was a larger contributor to the receptor measurements ( $31 \%$ of the total variance) than combustion sources during July in Detroit. This component included strong positive component loadings on GOM, $\mathrm{O}_{3}$, temperature and wind speed, and negative loadings on relative humidity (Lynam and Keeler, 2006). Other studies also extracted a component representative of GEM oxidation with similar pollutant or meteorological parameter loadings; however, the component did not explain the most variance with percentages ranging from 11 to $27 \%$ (Li et al., 2008; Huang et al., 2010; Cheng et al., 2012, 2013a; Ren et al., 2014; Xu et al., 2014). GEM oxidation was also inferred from a PCA component containing GOM, $\mathrm{BrO}$ and $\mathrm{O}_{3}$ (Ren et al., 2014). Although $\mathrm{BrO}$ and $\mathrm{O}_{3}$ are potential oxidants of GEM, it is unclear from this component whether the oxidation reaction was dominated by $\mathrm{BrO}$ or $\mathrm{O}_{3}$ and occurring in the gas, liquid, and/or solid phase. This example shows that inferring the GEM oxidation contribution from PCA results is complicated by $\mathrm{Hg}$ chemistry uncertainties. This component could also be interpreted as a combined effect from several oxidants or the co-occurrence of $\mathrm{O}_{3}, \mathrm{BrO}$ and GOM photochemical reactions because the strong loadings on the parameters is due to their strong correlations and not necessarily reflective of any causal relationships.

Diurnal mixing was also identified as the primary component affecting GEM concentrations in Detroit (Liu et al., 2007). The component explained $27 \%$ of the variance in the data set and was composed of negative component loadings for GEM, PBM and other primary pollutant variables $\left(\mathrm{SO}_{2}\right.$ and $\mathrm{NO}_{x}$ ), and positive loadings for $\mathrm{O}_{3}$. It is consistent with daytime mixing between the surface air and cleaner air aloft, which likely resulted in the lower GEM and PBM concentrations in the afternoon. Photochemical production of $\mathrm{O}_{3}$ also occurs during daytime. Liu et al. (2007) also confirmed that the principal component scores were higher for daytime data than nighttime, indicating that this component contributed more to daytime measurements. In contrast to diurnal mixing, another study obtained strong component loadings on GEM and other primary air pollutants for the nighttime data subset, which was largely attributed $(40.3 \%$ of the total variance) to nocturnal atmospheric inversion in Göteberg, Sweden (Li et al., 2008). During nighttime atmospheric inversion, air near the surface is colder and denser than the air above it, which leads to reduced mixing and inhibits air pollutant dispersion.

Snowmelt and evasion from the ocean are two processes that were identified from PCA as potential sources of GEM. Snowmelt was inferred from PCA of the winter data subsets from Rochester, New York (Huang et al., 2010), and explained the most variance in the winter data (19-21\%). The study obtained positive component loadings on GEM, temperature, and a "melting" variable, which is coded based on temperature ranges above $0{ }^{\circ} \mathrm{C}$. Additional analysis also confirmed that the average GEM concentrations corresponding to temperatures above $0^{\circ} \mathrm{C}$ were statistically higher than those below $0{ }^{\circ} \mathrm{C}$. Instead of snow melting, Eckley et al. (2013) collected snow depth data and obtained a negative loading for the component assigned to surface GEM emission. Evasion of GEM from the Atlantic Ocean was recognized as a potential source of GEM to a coastal site in Atlantic Canada (Cheng et al., 2013a). PCA produced a component with high loadings on GEM, relative humidity, wind speed, and precipitation, which explained 12-25\% of the variance in the data set. Further analysis using absolute principal component scores and back trajectory data indicated that this component impacted sampling days that were influenced by marine airflows. Back trajectories originating from the Atlantic Ocean were also associated with higher relative humidity and wind speed, which is consistent with the component loadings. The meteorological variables present in both of these components are also consistent with those observed in field studies (Lalonde et al., 2003; Laurier et al., 2003).

A component representing PBM wet deposition was also extracted from data sets collected in Rochester (Huang et al., 2010) and Huntington Wildlife Forest (Cheng et al., 2013a), New York. Hg wet deposition was inferred from the presence of high negative loadings for PBM and positive loadings for precipitation and relative humidity. Huang et al. (2010) also reported negative loadings on barometric pressure, since low atmospheric pressure leads to precipitation. $\mathrm{Hg}$ wet deposition explained $12-14 \%$ of the variance in the seasonal data subset (Huang et al., 2010) and $8 \%$ of the variance in an annual data set (Cheng et al., 2013a).

\subsubsection{Site characteristics on PCA results}

Some unique factors have been identified owing to site characteristics, such as a high altitude location, urban site, and forested area. A component consisting of GOM, $\mathrm{O}_{3}$, and water vapor was the primary component extracted from a data set (47\% of the total variance) collected at a high altitude site in the Mount Bachelor Observatory in Oregon, US. It was interpreted as transport from the free troposphere because of a positive component loading on $\mathrm{O}_{3}$ and a negative component on water vapor (i.e., dry air) which are characteristics of the upper atmosphere (Swartzendruber et al., 2006). Unlike other studies, the presence of $\mathrm{O}_{3}$ was not indicative of its role as a potential oxidant of GEM. This elevated site $(2.7 \mathrm{~km}$ above sea level) was frequently impacted by the free troposphere because of the diurnal cycle of mountain winds and offshore winds from the Pacific Ocean (Swartzendruber, 2006). Mountain winds move upslope during daytime. At night, free troposphere transport is driven by downslope winds. The influence of the free troposphere has been verified by performing additional back trajectory analysis (see Sect. 3.4). Dry upper troposphere air also impacted other high elevation sites (Faïn et al., 2009; Timonen et al., 2013). Faïn et al. (2009) observed an anti-correlation between GOM and GEM during low relative humidity conditions, while GOM was not re- 
lated to other air pollutants or $\mathrm{O}_{3}$. Timonen et al. (2013) suggested that GEM oxidation by $\mathrm{O}_{3}$ and halogens and heterogeneous chemistry may occur during long-range transport of air masses from Asia. GEM oxidation by halogens can also occur in clean air masses originating from the Pacific Ocean. These findings are consistent with the rapid GEM oxidation by bromine occurring in the free troposphere simulated in atmospheric Hg models (Holmes et al., 2006). However, there is still ongoing debate on which atmospheric oxidants are involved in GEM oxidation.

In urban sites, GEM oxidation and industrial sulfur are the top two components. Transport was the most frequent component in rural settings. Huang et al. (2010) suggested that the aqueous-phase reaction of GEM with $\mathrm{O}_{3}$ in some regions may be the most important oxidation process. Huang et al. (2010), Akhtar (2008), and Lynam and Keeler (2006) determined industrial sulfur was a major factor affecting mercury. The study by Lynam and Keeler (2006) was located in Detroit, Michigan, which was close to industrial areas. Akhtar (2008)'s study was conducted in Windsor, Ontario, Canada, downwind of several industrial states in the US, including Michigan, Ohio, and Indiana. The study of Huang et al. (2010) was carried out in Rochester, downwind of large coal-fired power plants located in western New York.

Forest fire smoke was inferred from PCA results which had positive loadings on TGM and the components of forest fire smoke, namely $\mathrm{PM}_{2.5}, \mathrm{CO}$, and $\mathrm{NH}_{3}$ (Parsons et al., 2013). This study was conducted in Alberta, Canada, where the forest density and occurrence of forest fires are both high. TGM / CO emissions ratios have also been used to differentiate the impact of biomass burning from anthropogenic emissions on receptor measurements. Based on aircraft and high altitude measurements, the median TGM/CO ratio can range from 1.3 to $9.2 \mathrm{pg} \mathrm{m}^{-3} \mathrm{ppb}^{-1}$ among different regions. A low TGM / CO ratio $\left(1-2 \mathrm{pg} \mathrm{m}^{-3} \mathrm{ppb}^{-1}\right)$ is clearly attributed to biomass burning plumes, whereas a higher TGM / CO ratio $\left(>6 \mathrm{pg} \mathrm{m}^{-3} \mathrm{ppb}^{-1}\right)$ is strongly indicative of anthropogenic emissions (Ebinghaus et al., 2007; Weiss-Penzias et al., 2007; Slemr et al., 2014). The TGM / CO ratio could be used in PCA for this purpose when a component contains only TGM and $\mathrm{CO}$ and no other chemical species markers are available. A potential method could be to calculate the absolute principal components scores (APCS) and convert it to a pollutant's source mass contribution to the receptor measurements (Thurston and Spengler, 1985). The TGM / CO ratio calculated from TGM and CO's source mass contributions are then compared with the emission ratios for biomass burning and anthropogenic plumes. The APCS method may be extended to TGM / $\mathrm{CO}_{2}$ and $\mathrm{TGM} / \mathrm{CH}_{4}$ ratios to gain insight into where the plumes originated from by comparing the ratios to those in literature (e.g., Slemr et al., 2014). Aside from forest fires, road-salt particles were identified as a potential PBM source at another forested site because of the existence of PBM, $\mathrm{Na}^{+}$, and $\mathrm{Cl}^{-}$. The authors pointed out that the most probable source of PBM during winter is the road dust which contains road salt and PBM via absorption or condensation of gaseous Hg (Cheng et al., 2012, 2013a).

\subsubsection{PCA results from data subsets}

To investigate different effects of $\mathrm{Hg}$ sources or atmospheric processes on annual, seasonal or diurnal scales, some studies divided the full data set into subsets for additional PCA investigations. All papers reported differences between the subsets and between the full data set and the subsets to some extent (Gao, 2007; Parsons et al., 2013, Xu et al., 2014). In the 2007-2011 Windsor, Ontario, TGM study (Xu et al., 2014), seasonal PCA revealed that the transport component seems to be very influential to TGM concentrations due to high winds. The impact of GEM oxidation was more easily extracted from the springtime data because there are less confounding factors, e.g., re-emission of GEM. When analyzed by year, similar results were obtained as with the full data set. In a study conducted in Ohio, two factors (coal-fired power plants and GEM oxidation) were extracted from the full data set. The PCA result from summer subset was similar, component one being coal-fired power plants and GEM oxidation, and component two being combustion. The winter subset also had two factors retained: combustion and coalfired power plants, however, without GEM oxidation (Gao, 2007).

Similarly, TGM data collected in Fort McMurray, Alberta, were stratified into three concentration ranges and then each data subset were analyzed separately using PCA (Parsons et al., 2013). For the full data set, TGM variability was primarily attributed to diurnal variability followed by forest fire smoke, temperature and snow depth, industrial sulfur, and combustion processes. However, when the highest onethird TGM concentration subset was analyzed, the two major $\mathrm{Hg}$ components extracted were forest fire smoke and diurnal variability. This suggests that elevated TGM concentrations were not strongly attributed to oil sand activities. The middle one-third and lowest one-third TGM concentration ranges show the same result as the full data set with diurnal variability as the major $\mathrm{Hg}$ component.

\subsubsection{TGM vs. speciated atmospheric Hg PCA results}

In terms of the benefits of collecting speciated $\mathrm{Hg}$ data over TGM only in PCA, data sets with speciated $\mathrm{Hg}$ were more likely to identify GEM oxidation (5 of 10 vs. 2 of 10 publications), combustion sources (4 vs. 2 publications), and diurnal trend ( 3 vs. 1 publications) as the major components affecting $\mathrm{Hg}$ than data sets with TGM only. The analysis of speciated atmospheric Hg has a greater tendency of extracting these three components because the variations in GOM and PBM are attributable to fresh emissions, chemical reactions and diurnal patterns in the atmosphere, whereas GEM or TGM are subject to large and stable background concentrations. This is further supported by Wan et al. (2009b) and 
Liu et al. (2007), who reported that PBM has a similar diurnal pattern as GOM. Specifically, GOM generally peak from midday to afternoon, and is quickly removed by nighttime dry deposition. A comparison of TGM and speciated $\mathrm{Hg}$ PCA results was also examined by Wan et al. (2009a, b). The same data set was analyzed twice. The initial analysis with TGM only resulted in meteorological conditions as the major $\mathrm{Hg}$ component (Wan et al., 2009a). When all three $\mathrm{Hg}$ species were included, diurnal trend and combustion processes were identified as the major $\mathrm{Hg}$ components (Wan et al., 2009b).

Of all $\mathrm{Hg}$ components reported in 10 speciated $\mathrm{Hg}$ studies, one-half of the components involved GOM while only $10 \%$ of the components contained all three $\mathrm{Hg}$ species. PBM tended to cluster on a component with GEM or GOM rather than on a separate factor, indicating that these species may undergo gas-particle partitioning (Lynam and Keeler, 2006). None of the components had GEM and GOM clustered together, suggesting differences in the strength of sources and sinks for GEM and GOM.

\subsubsection{PCA results summary}

Due to the inherent difficulties in component interpretation, some PCA studies were not able to characterize certain components due to a lack of data/evidence. For example, Cheng et al. (2009) derived a major $\mathrm{Hg}$ component with high loadings for all three $\mathrm{Hg}$ species and $\mathrm{PM}_{2.5}$ only, which could not be easily characterized without additional data. Wan et al. (2009b) were unable to differentiate two of the components, which were only labeled "Combustion processes I" and "Combustion processes II". Most PCA studies have gone beyond apportioning conventional anthropogenic sources to even identifying chemical and physical processes (e.g., GEM oxidation, boundary layer mixing, and surface GEM flux). The inclusion of meteorological parameters has helped with the interpretation of $\mathrm{Hg}$ processes. However, the profiles for these $\mathrm{Hg}$ processes and some non-point sources are not wellestablished. The qualitative interpretation of the components is based on literature. A few PCA studies included other receptor model (e.g., back trajectory models and absolute principal component scores) results to support the PCA findings. PCA results were often verified by performing analysis of seasonal and diel trends in atmospheric $\mathrm{Hg}$, correlations between $\mathrm{Hg}$ and ancillary air pollutants, and wind speeds and wind directions. Despite the supplementary data analysis, PCA results for speciated atmospheric $\mathrm{Hg}$ are rarely evaluated. Only a few studies have compared PCA output to other data reduction or data classification outputs, such as a positive matrix factorization (PMF) model and cluster analysis (Cheng et al., 2009, 2012).

\subsection{PMF Results}

The PMF model apportioned sources of speciated atmospheric $\mathrm{Hg}$ measured in Potsdam (Liu et al., 2003) and Rochester (Wang et al., 2013), New York, and Toronto, Canada (Cheng et al., 2009). PMF inferred industrial sources, such as nickel smelting and metal production, as potential contributors to atmospheric Hg in Potsdam, New York, and Toronto, Canada. Among the seven factors extracted from the Potsdam site, GEM was found in trace concentrations in one factor containing Se and $\mathrm{S}$, which are characteristic of nickel smelting. This source was also verified by PSCF, which indicated that the probable source areas were nickel smelting operations in central Quebec and eastern Ontario (Liu et al., 2003). Metal production was also identified as a potential source contributing to GOM and PBM concentrations in Toronto based on comparison of the pollutant ratios (e.g., $\mathrm{NO}_{2} / \mathrm{TGM}, \mathrm{PM}_{2.5}$ / TGM, and $\mathrm{SO}_{2}$ / TGM) between factor profiles and source profiles from emissions inventories (Cheng et al., 2009). However, due to the large variability in the source emissions ratios among metal production plants, several factor profiles were assigned to production of metals. The source with the most unique and least variability in the source emissions ratios was sewage treatment; thus, one of the factors was easily interpreted as sewage treatment. Of all GEM concentrations, $84 \%$ were attributed to this source. This study highlighted the potential issues with multivariate models, such as non-unique factor profiles, that can arise due to a lack of chemical species markers in the data set. If trace metals or aerosol chemical composition data were available at this receptor location, $\mathrm{Zn}, \mathrm{Pb}, \mathrm{Cu}, \mathrm{Cl}, \mathrm{V}$, and $\mathrm{Ni}$ could be used as chemical species markers for municipal waste disposal/incineration (Graney et al., 2004; Keeler et al., 2006; Watson et al., 2008). In the absence of this data, potential $\mathrm{Hg}$ sources in urban areas may have been neglected, such as GEM emissions from urban surfaces and soil (Eckley and Branfireun, 2008) and vehicular traffic (Landis et al., 2007).

Inclusion of $\mathrm{CO}$ and aerosol measurements in Rochester was practical for assigning factors from the PMF model to traffic and wood combustion sources and the process of nucleation. Out of these three factors, however, only wood combustion contributed significantly to PBM concentrations $(48 \%)$ as well as to ultrafine and fine particle number concentrations and Delta-C. PBM contribution from wood combustion was comparable to that from a local coal-fired power plant (CFPP) in Rochester. The source with the largest contribution to GEM concentrations was a factor with enhanced ozone contributions (50\%). Factors representing CFPP and GEM oxidation contributed 50 and $85 \%$, respectively, to GOM concentrations (Wang et al., 2013). The PMF model was also applied to the data set collected before and after the shutdown of the CFPP to show the change in the impact of this source on speciated atmospheric Hg in Rochester. CFPP contribution declined by $25 \%$ for GEM, $74 \%$ for GOM, and $67 \%$ for PBM after the CFPP was shutdown. These results 
were also verified by condition probability function, which showed a substantial decrease in the probability of observing elevated concentrations from the wind direction of the CFPP after its closure (Wang et al., 2013).

There were only a few studies that have used the PMF model to apportion sources of speciated atmospheric $\mathrm{Hg}$. The studies identified local and regional sources and chemical and physical processes impacted speciated atmospheric $\mathrm{Hg}$. The PMF model was also capable of investigating the change in source emissions on speciated atmospheric $\mathrm{Hg}$ at a receptor site. Having a sufficient number of chemical species markers in the data set is conducive to the interpretation of the model factors and also ensures that some sources have not been omitted. To verify the anthropogenic point sources resolved from the PMF model, studies performed further analysis using PSCF and conditional probability function. Unlike the PCA studies, some discussion was provided on the goodness of fit of the PMF model. However, the sources inferred have not been independently assessed for accuracy in PMF studies of speciated atmospheric $\mathrm{Hg}$. In comparison, source-based $\mathrm{Hg}$ transport models can evaluate the predicted speciated atmospheric $\mathrm{Hg}$ concentrations against field measurements.

\subsection{PSCF results}

PSCF was applied to receptor locations in North America and Asia, such as Potsdam, Stockton, Sterling (Han et al., 2005, 2007) and Huntington Wildlife Forest (Choi et al., 2008), New York; Salmon Falls Creek, Idaho (Abbott et al., 2008); Windsor, Ontario, Canada (Xu and Akhtar, 2010); Guiyang, Waliguan, and Mt. Changbai, China (Fu et al., 2011, 2012a, b); and Yeongheung Island, South Korea (Lee et al., 2014). Most of the studies used PSCF to analyze TGM or GEM data, with the exception of two studies that analyzed speciated atmospheric $\mathrm{Hg}$ as well (Han et al., 2005; Choi et al., 2008).

Four of the PSCF studies were conducted in the Great Lakes region close to Lake Erie and Lake Ontario. These studies identified potential source areas to the south of the receptor site spanning from the Ohio River valley, which is known for its industrialized areas, to Texas. From these potential source areas, the studies located $\mathrm{Hg}$ point sources from emissions inventory, such as coal combustion in Ohio and Pennsylvania, waste incineration and oil combustion in St. Louis, and metal smelting in Ontario and Quebec. The Atlantic Ocean and Gulf of Mexico were also recognized as potential sources of GEM and TGM through potential photoreduction of $\mathrm{Hg}(\mathrm{II})$ in the ocean and volatilization of GEM from the ocean surface (Han et al., 2007; Xu and Akhtar, 2010). In a western US site, GEM was attributed to $\mathrm{Hg}$ point sources, gold mining, natural $\mathrm{Hg}$-enriched areas in Nevada, and wildfires (Abbott et al., 2008). At receptor locations in China, PSCF identified potential source regions of TGM and GEM in north-central China, northwestern India, and North
Korea (Fu et al., 2011, 2012a, b). In these regions, Hg emissions originate from coal combustion, cement production, and urban and industrial areas. Mercury emissions in northeastern China and local industrial emissions also contributed to elevated TGM in South Korea (Lee et al., 2014).

Seasonal PSCF analysis revealed potential source areas that were not recognized in PSCF analysis of long-term data. The change in the prevailing winds in Guiyang, China, during the summer was driven by monsoons, which led to the identification of potential source areas southeast of Guiyang (Fu et al., 2011). In Windsor, Canada (Great Lakes region), PSCF analysis of the winter and spring TGM data revealed potential source areas in the northwest and northeast directions, whereas the source areas based on the PSCF analysis of the annual data were predominantly transboundary pollution from the US (Xu and Akhtar, 2010). Xu and Akhtar (2010) attributed this finding to the use of seasonal means to perform seasonal PSCF analysis because more sampling days were above the seasonal mean concentration threshold than the annual mean.

PSCF results were correlated with $\mathrm{Hg}$ point source emissions data in a few PSCF studies (Han et al., 2005, 2007; Choi et al., 2008). Correlation coefficients ranged from 0.34 to 0.55 and appeared to be dependent on trajectory model parameters and $\mathrm{Hg}$ emissions data used. Han et al. (2005) obtained stronger correlations for a trajectory model, which simulated dispersion, than those of a single trajectory model and a trajectory model simulating both dispersion and deposition. The duration of the trajectory for simulating GEM transport also affected the correlation results. When longer trajectories (i.e., 5-day) were used in PSCF and were correlated with total $\mathrm{Hg}$ emissions (sum of GEM, GOM and PBM), correlation coefficients were higher than PSCF analysis using 3-day trajectories (Han et al., 2007). On the contrary, shorter trajectories used in PSCF produced better agreement with the emissions inventory for GEM only. In the GOM source-receptor relationship study, Han et al. (2005) compared PSCF results to the GOM emissions inventory but noted that the uncertainties in the GOM emissions inventory are likely larger than those of GEM. The studies attributed the weak to moderate correlations between PSCF results and $\mathrm{Hg}$ point source emissions to emissions database uncertainties, such as the use of emission factors instead of measurements to determine $\mathrm{Hg}$ emissions, and an incomplete $\mathrm{Hg}$ emissions inventory.

Source-receptor trajectory model intercomparison was conducted between PSCF, residence time weighted concentration (RTWC), and simplified quantitative transport bias analysis (SQTBA) in one of the studies conducted in the Great Lakes region (Han et al., 2007). The study found that using redistributed concentrations along a trajectory in the RTWC model helped narrow down the potential source area to the Ohio River valley and Indiana. In contrast, the PSCF results indicated a much larger source region stretching from Ohio to Texas. The redistribution of the concentrations in 
RTWC prevented the identification of potential source areas downwind and upwind of actual point sources, which is known as the trailing effect. The trailing effect also led to the overestimation of the impact of regional source areas on GEM concentrations in Guiyang, China, because of significant local $\mathrm{Hg}$ sources along the same direction (Fu et al., 2011). Additional analysis of wind speeds measured in Guiyang was performed to assess the impact of local sources. The impact of local urban areas on TGM in Mt. Changbai, China, was not identified by PSCF because the model resolution of the back trajectories was not suitable for simulating local winds (Fu et al., 2012b). Potential mixing between regional airflows and local winds is also a major uncertainty of the PSCF model (Xu and Akhtar, 2010).

PSCF studies on speciated atmospheric Hg identified the regional transport of emissions from $\mathrm{Hg}$ point sources, urban areas, and from the ocean. The studies typically reported potential source areas covering a large geographical area because the size of the model grid cells used in the studies is too coarse to accurately locate the point sources. In contrast to the multivariate models, the PSCF studies rarely discussed potential $\mathrm{Hg}$ emissions from forest fires, wood combustion, GEM oxidation, crust and soil, and snow melting in the high probability source regions. The PSCF model can be independently evaluated to some degree using $\mathrm{Hg}$ emissions data unlike the multivariate models; however, this has only been performed in a few PSCF studies. Based on the limited evaluation of PSCF, trajectory parameters, trailing effect, and $\mathrm{Hg}$ emissions data remain to be the major PSCF uncertainties and limitations. Therefore, PSCF is more suitable for receptor locations that are potentially impacted by regional or long-range sources rather than locations that are downwind of major local sources. If only PBM are measured, these models would be more suitable for receptor locations that are potentially impacted by regional sources and less suitable for identifying distant sources because of the shorter residence time of aerosols.

\subsection{GFD results}

GFD analyses on the horizontal and vertical distribution of trajectory endpoints corresponding to GOM enhancement events were conducted in desert valley sites in Nevada (Weiss-Penzias et al., 2009) and coastal sites in the US southeast (Weiss-Penzias et al., 2011; Gustin et al., 2012). The GFD plots for the Nevada sites showed a larger number of trajectory endpoints above the model boundary layer for elevated GOM concentrations (i.e., upper quartile GOM) than lower quartile GOM concentrations (Weiss-Penzias et al., 2009). Modeled rainfall amounts were also lower for elevated GOM concentrations. These results indicate the Nevada sites were influenced by transport from the free troposphere. Further analysis of the trajectory residence time within a 3-D source box defined by latitudes $<35^{\circ} \mathrm{N}$ and altitudes $>2 \mathrm{~km}$ was also conducted. The study found longer trajectory res- idence time for the upper quartile GOM than lower quartile GOM, which provided additional support for the upper atmospheric transport hypothesis (Weiss-Penzias et al., 2009). Transport from the upper atmosphere also contributed to some of the GOM enhancement events in the US southeast (Weiss-Penzias et al., 2011). Compared to GOM enhancement events that were attributed to local coal combustion sources, a higher number of grid cells had $>75 \%$ of the trajectory endpoints above the model boundary layer for the GOM enhancement events that were impacted by the free troposphere. For these GOM events, the distances covered by the trajectories were longer, which indicated higher wind speeds and long-range transport. A majority of the grid cells also showed less rainfall, which is consistent with the drier air from the free troposphere. Similar GFD results were also obtained at three coastal sites in Florida (Gustin et al., 2012). GOM enhancement events were partially due to local electricity generating plants and long-range transport as well as transport from the free troposphere. In the latter case, higher GOM concentrations were accompanied by higher mean PBM, which may be consistent with GOM partitioning to aerosols in the upper atmosphere. This theory is supported by speciated atmospheric $\mathrm{Hg}$ measurements and modeling in the free troposphere (Murphy et al., 2006; Selin and Jacob, 2008; Holmes et al., 2009; Lyman and Jaffe, 2012).

GFD analysis of trajectory ensemble data has only been applied to elevated GOM events in the western and southeastern US. The studies verified the impact of local power plants and found evidence of free troposphere transport of GOM and PBM. Compared to PSCF studies, the GFD results offered less insight into regional $\mathrm{Hg}$ sources contributing to the receptor sites. Potential reasons could be because $\mathrm{Hg}$ sources contribute to the global atmospheric $\mathrm{Hg}$ pool rather than specific receptor sites, and it may not be possible to further separate the elevated GOM events by local source and regional source impacts. Consequently, GOM enhancements at the receptor sites were largely explained by local source and free troposphere effects in the GFD studies.

\subsection{CFA, RTWC, and CWT results}

CFA, RTWC, and CWT have been used to identify potential sources of TGM and speciated atmospheric $\mathrm{Hg}$ contributing to multiple sites in New York (Han et al., 2007), Mexico City (Rutter et al., 2009), Milwaukee, Wisconsin (de Foy et al., 2012); and Dartmouth, Nova Scotia (Cheng et al., 2013b). The New York and Milwaukee sites in the Great Lakes region and the Nova Scotia site identified industrial areas in Ohio and the eastern US as potential $\mathrm{Hg}$ sources (Han et al., 2007; de Foy et al., 2012; Cheng et al., 2013b). The source areas identified by the RTWC model also revealed that metal industries in Quebec and Ontario, Canada, contributed to TGM in New York (Han et al., 2007). These source areas also affected GOM and PBM concentrations at the Nova Scotia site based on CWT results (Cheng et al., 2013b). Han 
et al. (2007) credited the findings to the scaling of trajectory residence time using the receptor TGM concentrations, which were relatively higher at one of the sites near Canada. $\mathrm{Hg}$ sources in Canada were not identified by PSCF because the trajectory residence times for some grid cells may have been the same for average to high TGM concentrations according to Eq. (4) (Han et al., 2007). In Milwaukee, the Great Lakes were also recognized by CFA as a potential source of GEM emissions with an estimated flux between 12000 and $14000 \mathrm{~kg}$ over the 1-year study period (de Foy et al., 2012). Similarly, higher CWT values for GEM in the Atlantic Ocean all year round suggested that the evasion of GEM from the ocean was a potential source of GEM in Nova Scotia (Cheng et al., 2013b). CFA results for the Mexico City sites indicated that the sites were impacted by known $\mathrm{Hg}$ point sources, such as cement and chemical production and paper and cardboard manufacturing, and by potential unregistered sources and volcanic emissions (Rutter et al., 2009).

The CFA study of the receptor sites in Mexico City identified the same source areas for GEM and GOM and for the urban and rural site. The consistency in the results suggest that the model was capable of identifying the major source areas contributing to speciated atmospheric $\mathrm{Hg}$ (Rutter et al., 2009). RTWC and CWT model results were independently evaluated using $\mathrm{Hg}$ emissions data from point sources. Han et al. (2007) obtained a correlation coefficient of 0.19 between RTWC values for TGM and total $\mathrm{Hg}$ emissions in the model grid cells. In another study, the correlation coefficient between CWT values for PBM and total $\mathrm{Hg}$ emissions in the model grid cells was 0.27 , but no relationships were found between CWT values for GEM and GOM and total Hg emissions (Cheng et al., 2013b). In fact, this study found that almost all major source areas of GEM identified by CWT were not associated with any $\mathrm{Hg}$ point source emissions. Potential explanations for the weak correlation with industrial $\mathrm{Hg}$ emissions are the large spatial variability between moderate and strong source regions (Han et al., 2007) and the exclusion of $\mathrm{Hg}$ emissions data from non-point $\mathrm{Hg}$ sources, such as biomass burning, wildfires, surface mining, and from oceans, lakes, soil, and vegetation (Cheng et al., 2013b). Studies have also discussed potential unregistered Hg sources (Rutter et al., 2009; Cheng et al., 2013b) and the need for additional field measurements to quantify their $\mathrm{Hg}$ emissions. Due to the limitations and uncertainties of the $\mathrm{Hg}$ emissions database, an alternative approach was used to assess the CWT model accuracy by verifying that there were no $\mathrm{Hg}$ point source emissions in the weak source regions (Cheng et al., 2013b).

The trailing effect issue was raised in most of the studies. Like PSCF, the CFA, RTWC, and CWT models may not be able to distinguish between upwind and downwind source areas. For example, a single trajectory associated with a very high $\mathrm{Hg}$ concentration at a receptor location could overestimate the impact of distant sources (Rutter et al., 2009; de Foy et al., 2012). A potential solution to the trailing effect is to redistribute the concentrations along the trajectory segment for every trajectory prior to determining the concentration fields, RTWC, or CWT (Stohl, 1996; Han et al., 2007). de Foy et al. (2012) also suggested using a polar grid, which may increase the overall residence time in the larger distant grid cells. Another way is to assess local source impacts by analyzing local wind patterns, such as conditional probability function (Cheng et al., 2013b). Other sources of uncertainties include variability in the trajectory distance with starting positions for single trajectory applications, $\mathrm{Hg}$ deposition, and turbulent mixing (Cheng et al., 2013b).

The CFA, RTWC, and CWT approaches attributed speciated atmospheric $\mathrm{Hg}$ at receptor locations to regional industrial areas with a high density of $\mathrm{Hg}$ point sources and $\mathrm{Hg}$ emissions from lakes and oceans. The sources identified are similar to PSCF but less comprehensive than the findings of atmospheric chemical and physical processes in the multivariate receptor modeling studies (see Table 1 summary of the receptor models discussed in this paper). While the objective in most CFA/RTWC/CWT and PSCF studies were to identify potential $\mathrm{Hg}$ point sources, these models can also be used at receptor locations that are potentially impacted by area sources (e.g., Hg emissions from lakes, ocean, forest fires, traffic) as shown in de Foy et al. (2012). CFA, RTWC, and CWT results for speciated atmospheric $\mathrm{Hg}$ have been independently evaluated to only some extent because of limitations and uncertainties of the $\mathrm{Hg}$ emissions database and the few model intercomparisons conducted. Similar to PSCF, trajectory model parameters and trailing effect uncertainties also apply to CFA, RTWC, and CWT. Therefore, some of the receptor location considerations for PSCF discussed in Sect. 3.3 also apply to the CFA/RTWC/CWT models. Overall, back trajectory receptor models are more accurate at identifying the direction of potential sources rather than the distance of sources to the receptor location (Han et al., 2007; Rutter et al., 2009; de Foy et al., 2012).

\section{Recommendations and future research directions}

\subsection{Multivariate receptor models}

1. There are only a few studies that have applied the PMF model to speciated atmospheric $\mathrm{Hg}$ data. Future research could take advantage of the data quality screening features in the PMF model because of the large uncertainties in GOM and PBM measurements that are expected to influence model results.

2. The majority of PCA and PMF studies used for source apportionment of speciated atmospheric $\mathrm{Hg}$ have not included enough chemical species markers to infer specific types of combustion sources. This requires trace element measurements that are collocated with speciated atmospheric $\mathrm{Hg}$ measurements. 
3. PCA and PMF studies found that anthropogenic and natural $\mathrm{Hg}$ sources and chemical and physical processes affected receptor measurements of speciated atmospheric $\mathrm{Hg}$. Future research could focus on determining the characteristics, e.g., chemical composition and mercury speciation profiles, of mercury sources and chemical and physical processes in the atmosphere.

4. Methods are not available to independently evaluate the accuracy of the mercury sources and chemical and physical processes inferred from the multivariate models. One potential method previously proposed by Watson et al. (2008) could be to utilize the multivariate model results from a particular receptor site in source-based chemical transport models and assess the accuracy of the model-predicted concentrations at the receptor site.

\subsection{Back trajectory receptor models}

1. The back trajectory receptor model results are primarily affected by uncertainties in back trajectory modeling of speciated atmospheric $\mathrm{Hg}$, such as trajectory duration and starting position selected, simulations with or without dispersion, and potential deposition and chemical and physical processes along the trajectory pathway. Due to the variability in the trajectory distances with starting position of the trajectory, ensemble trajectories should be generated in PSCF, RTWC, and CWT models. Further studies are needed to determine how the model results are affected by modifications to input data and model parameters.

2. Uncertainties in the back trajectory receptor models are also attributed to the trailing effect and increasing number of trajectory endpoints approaching the receptor location. The trailing effect may identify false source areas downwind or upwind of actual sources. Redistributing the concentrations along the trajectories is a potential solution for the CFA, RTWC, and CWT models, but the trailing effect issue has not been resolved for models that do not explicitly use receptor concentrations (e.g., PSCF and GFD). The increasing number of trajectory endpoints approaching the receptor location leads to the potential false identification of sources near the receptor location in the GFD since a longer residence time indicates a greater likelihood of contributing to the receptor site. It also affects the PSCF calculation. Overall, these models are not suitable for identifying local source areas unless the sources can be verified by $\mathrm{Hg}$ emissions data. An alternative method to assess local source impacts would be to analyze local wind measurements.

3. There are only a few studies that have independently evaluated the back trajectory receptor model results either by model intercomparisons or by correlating with $\mathrm{Hg}$ point source emissions data. More evaluations for the PSCF, GFD, CFA, RTWC, and CWT models are needed to determine the accuracy of the $\mathrm{Hg}$ sources identified, and a comprehensive and updated $\mathrm{Hg}$ emissions inventory should be used in the evaluation to ensure all natural and anthropogenic sources and mercury speciation are considered.

4. GOM and PBM measurement uncertainties are likely to impact the back trajectory receptor model results in terms of the selection of the concentration threshold in PSCF, determination of elevated $\mathrm{Hg}$ events in GFD analysis, and use of concentrations to weight trajectory residence time in CFA, RTWC, and CWT. Future studies need to determine how the model results are affected by the use of lower or higher receptor concentrations.

Speciated atmospheric mercury measurements should be considered the key element to obtaining high quality mercury source-receptor results and further advancing the knowledge of mercury behavior in the atmosphere. It is recommended to conduct source-receptor studies for total oxidized mercury $(\mathrm{GOM}+\mathrm{PBM})$ and compare results with those using speciated $\mathrm{Hg}$. This is because uncertainties in measured GOM and PBM are large, e.g., due to technology limitations separating PBM from GOM using the Tekran instruments. The same framework can also be used for sensitivity tests by manipulating PBM and GOM data points below method detection limit. Such practises can shed some light on scientific questions, such as to what extent the uncertainties in GOM and PBM data would affect the receptor modeling results, and which approaches are more effective in mitigating such bias, removing data at or below detection limits or combining GOM and PBM in the analysis? Receptor modeling results for speciated $\mathrm{Hg}$ should also be compared with those only using GEM to identify similarities and differences. This may tell us if using speciated $\mathrm{Hg}$ data will lead to a better understanding of sources and atmospheric processes than just using GEM data and, if so, under what scenarios (locations, sources, processes).

Acknowledgements. We greatly appreciate Xiaobin Wang at University of Windsor for providing technical assistance.

Edited by: R. Ebinghaus

\section{References}

Abbott, M. L., Lin, C.-J., Martian, P., and Einerson, J. J.: Atmospheric mercury near Salmon Falls Creek Reservoir in southern Idaho, Appl. Geochem., 23, 438-453, 2008.

Akhtar, U. S.: Atmospheric total gaseous mercury concentration measurement in Windsor: A study of variability and potential sources, MASc Thesis, University of Windsor, Windsor, Ontario, Canada, 2008. 
Belis, C. A., Karagulian, F., Larsen, B. R., and Hopke, P. K.: Critical review and meta-analysis of ambient particulate matter source apportionment using receptor models in Europe, Atmos. Environ., 69, 94-108, 2013.

Blanchard, P., Froude, F. A., Martin, J. B., Dryfhout-Clark, H., and Woods, J. T.: Four years of continuous total gaseous mercury (TGM) measurements at sites in Ontario, Canada, Atmos. Environ., 36, 3735-3743, 2002.

Chen, L. W. A., Watson, J. G., Chow, J. C., DuBois, D. W., and Herschberger, L.: $\mathrm{PM}_{2.5}$ source apportionment: reconciling receptor models for US nonurban and urban long-term networks, JAPCA J. Air Waste Ma., 61, 1204-1217, 2011.

Cheng, I., Lu, J., and Song, X.: Studies of Potential Sources that Contributed to Atmospheric Mercury in Toronto, Canada, Atmos. Environ., 43, 6145-6158, 2009.

Cheng, I., Zhang, L., Blanchard, P., Graydon, J. A., and Louis, V. L. St.: Source-receptor relationships for speciated atmospheric mercury at the remote Experimental Lakes Area, northwestern Ontario, Canada, Atmos. Chem. Phys., 12, 1903-1922, doi:10.5194/acp-12-1903-2012, 2012.

Cheng, I., Zhang, L., Blanchard, P., Dalziel, J., Tordon, R., Huang, J., and Holsen, T. M.: Comparisons of mercury sources and atmospheric mercury processes between a coastal and inland site, J. Geophys. Res.-Atmos., 118, 2434-2443, $2013 \mathrm{a}$.

Cheng, I., Zhang, L., Blanchard, P., Dalziel, J., and Tordon, R.: Concentration-weighted trajectory approach to identifying potential sources of speciated atmospheric mercury at an urban coastal site in Nova Scotia, Canada, Atmos. Chem. Phys., 13, 6031-6048, doi:10.5194/acp-13-6031-2013, 2013b.

Choi, H.-D., Holsen, T. M., and Hopke, P. K.: Atmospheric Mercury $(\mathrm{Hg})$ in the Adirondacks: Concentrations and Sources, Environ. Sci. Technol., 42, 5644-5653, 2008.

de Foy, B., Wiedinmyer, C., and Schauer, J. J.: Estimation of mercury emissions from forest fires, lakes, regional and local sources using measurements in Milwaukee and an inverse method, Atmos. Chem. Phys., 12, 8993-9011, doi:10.5194/acp-12-89932012, 2012.

Draxler, R. R. and Rolph, G. D.: HYSPLIT (HYbrid Single-Particle Lagrangian Integrated Trajectory), NOAA Air Resources Laboratory, College Park, MD, available at: http://www.arl.noaa.gov/ HYSPLIT.php (last access: 20 February 2015), 2014.

Ebinghaus, R., Slemr, F., Brenninkmeijer, C. A. M., Van Velthoven, P., Zahn, A., Hermann, M., O'Sullivan, D. A., and Oram, D. E.: Emissions of gaseous mercury from biomass burning in South America in 2005 observed during CARIBIC flights, Geophys. Res. Lett., 34, L08813, doi:10.1029/2006GL028866, 2007.

Eckley, C. S. and Branfireun, B.: Gaseous mercury emissions from urban surfaces: controls and spatiotemporal trends, Appl. Geochem., 23, 369-383, 2008.

Eckley, C. S., Parsons, M. T., Mintz, R., Lapalme, M., Mazur, M., Tordon, R., Elleman, R., Graydon, J. A., Blanchard, P., and St. Louis, V.: Impact of closing Canada's largest point-source of mercury emissions on local atmospheric mercury concentrations, Environ. Sci. Technol., 47, 10339-10348, 2013.

Faïn, X., Obrist, D., Hallar, A. G., Mccubbin, I., and Rahn, T.: High levels of reactive gaseous mercury observed at a high elevation research laboratory in the Rocky Mountains, Atmos. Chem. Phys., 9, 8049-8060, doi:10.5194/acp-9-8049-2009, 2009.
Fast, J. D. and Easter, R.: A Lagrangian Particle Dispersion Model Compatible with WRF, in: 7th WRF User's Workshop, Boulder, CO, USA, 2006.

Fu, X., Feng, X., Qiu, G., Shang, L., and Zhang, H.: Speciated atmospheric mercury and its potential source in Guiyang, China, Atmos. Environ., 45, 4205-4212, 2011.

Fu, X. W., Feng, X., Liang, P., Deliger, Zhang, H., Ji, J., and Liu, P.: Temporal trend and sources of speciated atmospheric mercury at Waliguan GAW station, Northwestern China, Atmos. Chem. Phys., 12, 1951-1964, doi:10.5194/acp-12-1951-2012, 2012a.

Fu, X. W., Feng, X., Shang, L. H., Wang, S. F., and Zhang, H.: Two years of measurements of atmospheric total gaseous mercury (TGM) at a remote site in Mt. Changbai area, Northeastern China, Atmos. Chem. Phys., 12, 4215-4226, doi:10.5194/acp12-4215-2012, $2012 b$.

Gao, F.: A comprehensive investigation of ambient Mercury in the Ohio River valley: source-receptor relationship and meteorological impact, Doctoral dissertation, Ohio University, Athens, Ohio, United States, 2007.

Graney, J. R., Dvonch, J. T., and Keeler, G. J.: Use of multi-element tracers to source apportion mercury in south Florida aerosols, Atmos. Environ., 38, 1715-1726, 2004.

Gustin, M. S., Weiss-Penzias, P. S., and Peterson, C.: Investigating sources of gaseous oxidized mercury in dry deposition at three sites across Florida, USA, Atmos. Chem. Phys., 12, 9201-9219, doi:10.5194/acp-12-9201-2012, 2012.

Gustin, M. S., Amos, H. M., Huang, J., Miller, M. B., and Heidecorn, K.: Measuring and modeling mercury in the atmosphere: a critical review, Atmos. Chem. Phys., 15, 5697-5713, doi:10.5194/acp-15-5697-2015, 2015.

Han, Y.-J., Holsen, T. M., Lai, S.-O., Hopke, P. K., Yi, S.-M., Liu, W., Pagano, J., Falanga, L., Milligan, M., and Andolina, C.: Atmospheric gaseous mercury concentrations in New York State: relationships with meteorological data and other pollutants, Atmos. Environ., 38, 6431-6446, 2004.

Han, Y.-J., Holsen, T. M., Hopke, P. K., and Yi, S.-M.: Comparison between Back-Trajectory Based Modeling and Lagrangian Backward Dispersion Modeling for Locating Sources of Reactive Gaseous Mercury, Environ. Sci. Technol., 39, 1715-1723, 2005.

Han, Y. J., Holsen, T. M., and Hopke, P. K.: Estimation of source locations of total gaseous mercury measured in New York State using trajectory-based models, Atmos. Environ., 41, 6033-6047, 2007.

Hegarty, J., Mao, H., and Talbot, R.: Synoptic influences on springtime tropospheric $\mathrm{O}_{3}$ and $\mathrm{CO}$ over the North American export region observed by TES, Atmos. Chem. Phys., 9, 3755-3776, doi:10.5194/acp-9-3755-2009, 2009.

Hegarty, J., Draxler, R. R., Stein, A. F., Brioude, J., Mountain, M., Eluszkiewicz, J., Nehrkorn, T., Ngan, F., and Andrews, A.: Evaluation of Lagrangian particle dispersion models with measurements from controlled tracer releases, J. Appl. Meteorol. Climatol., 52, 2623-2637, 2013.

Holmes, C. D., Jacob, D. J., and Yang, X.: Global lifetime of elemental mercury against oxidation by atomic bromine in the free troposphere, Geophys. Res. Lett., 33, L20808, doi:10.1029/2006GL027176, 2006. 
Holmes, C. D., Jacob, D. J., Mason, R. P., and Jaffe, D. A.: Sources and deposition of reactive gaseous mercury in the marine atmosphere, Atmos. Environ., 43, 2278-2285, 2009.

Hopke, P. K.: Recent developments in receptor modeling, J. Chemometr., 17, 255-265, 2003.

Hopke, P. K.: The Use of Source Apportionment for Air Quality Management and Health Assessments, J. Toxicol. Env. Heal. A, 71, 555-563, 2008.

Hopke, P. K. and Cohen, D. D.: Application of receptor modeling methods, Atmos. Pollut. Res., 2, 122-125, 2011.

Hopke, P. K., Ito, K., Mar, T., Christensen, W. F., Eatough, D. J., Henry, R. C., Kim, E., Laden, F., Lall, R., Larson, T. V., Liu, H., Neas, L., Pinto, J., Stölzel, M., Suh, H., Paatero, P., and Thurston, G. D.: PM source apportionment and health effects: 1. Intercomparison of source apportionment results, J. Expo. Sci. Environ. Epidemiol., 16, 275-286, 2005.

Huang, J., Choi, H.-D., Hopke, P. K., and Holsen, T. M.: Ambient Mercury Sources in Rochester, NY: Results from Principle Components Analysis (PCA) of Mercury Monitoring Network Data, Environ. Sci. Technol., 44, 8441-8445, 2010.

Jeong, U., Kim, J., Lee, H., Jung, J., Kim, Y. J., Song, C. H., and Koo, J.-H.: Estimation of the contributions of long range transported aerosol in East Asia to carbonaceous aerosol and PM concentrations in Seoul, Korea using highly time resolved measurements: a PSCF model approach, J. Environ. Monitor., 13, 19051918, doi:10.1039/c0em00659a, 2011.

Kabashnikov, V. P., Chaikovsky, A. P., Kucsera, T. L., and Metelskaya, N. S.: Estimated accuracy of three common trajectory statistical methods, Atmos. Environ., 45, 5425-5430, 2011.

Keeler, G. J., Landis, M. S., Norris, G. A., Christianson, E. M., and Dvonch, J. T.: Sources of mercury wet deposition in Eastern Ohio, USA, Environ. Sci. Technol., 40, 5874-5881, 2006.

Kim, K. H. and Kim, M. Y.: The temporal distribution characteristics of total gaseous mercury at an urban monitoring site in Seoul during 1999-2000, Atmos. Environ., 35, 4253-4263, 2001.

Kim, K. H., Shon, Z. H., Nguyen, H. T., Jung, K., Park, C. G., and Bae, G. N.: The effect of man made source processes on the behavior of total gaseous mercury in air: A comparison between four urban monitoring sites in Seoul Korea, Sci. Total Environ., 409, 3801-3811, 2011.

Kolker, A., Olson, M. L., Krabbenhoft, D. P., Tate, M. T., and Engle, M. A.: Patterns of mercury dispersion from local and regional emission sources, rural Central Wisconsin, USA, Atmos. Chem. Phys., 10, 4467-4476, doi:10.5194/acp-10-4467-2010, 2010.

Lalonde, J. D., Amyot, M., Doyon, M. R., and Auclair, J. C.: Photoinduced $\mathrm{Hg}$ (II) reduction in snow from the remote and temperate Experimental Lakes Area (Ontario, Canada), J. Geophys. Res., 108, 4200, doi:10.1029/2001JD001534, 2003.

Landis, M. S., Lewis, C. W., Stevens, R. K., Keeler, G. J., Dvonch, J. T., and Tremblay, R. T.: Ft. McHenry tunnel study: Source profiles and mercury emissions from diesel and gasoline powered vehicles, Atmos. Environ., 41, 8711-8724, 2007.

Laurier, F. J. G., Mason, R. P., Whalin, L., and Kato, S.: Reactive gaseous mercury formation in the North Pacific Ocean's marine boundary layer: A potential role of halogen chemistry, J. Geophys. Res., 108, 4529, doi:10.1029/2003JD003625, 2003.

Lee, G. S., Kim, P. R., Han, Y. J., Holsen, T. M., and Lee, S. H.: Tracing Sources of Total Gaseous Mercury to Yongheung Island off the Coast of Korea, Atmosphere, 5, 273-291, 2014.
Lee, J. H. and Hopke, P. K.: Apportioning sources of $\mathrm{PM}_{2.5}$ in St. Louis, MO using speciation trends network data, Atmos. Environ., 40, S360-S377, 2006.

Lee, S., Liu, W., Wang, Y., Russell, A. G., and Edgerton, E. S.: Source apportionment of $\mathrm{PM}_{2.5}$ : Comparing PMF and CMB results for four ambient monitoring sites in the southeastern United States, Atmos. Environ., 42, 4126-4137, 2008.

Li, J., Sommar, J., Wängberg, I., Lindqvist, O., and Wei, S.Q.: Short-time variation of mercury speciation in the urban of Göteborg during GÖTE-2005, Atmos. Environ., 42, 8382-8388, 2008.

Liu, B., Keeler, G. J., Dvonch, J. T., Barres, J. A., Lynam, M. M., Marsik, F. J., and Morgan, J. T.: Temporal variability of mercury speciation in urban air, Atmos. Environ., 41, 1911-1923, 2007.

Liu, W., Hopke, P. K., Han, Y. J., Yi, S. M., Holsen, T. M., Cybart, S., Kozlowski, K., and Milligan, M.: Application of receptor modeling to atmospheric constituents at Potsdam and Stockton, NY, Atmos. Environ., 37, 4997-5007, 2003.

Lyman, S. N. and Gustin, M. S.: Speciation of atmospheric mercury at two sites in northern Nevada, USA, Atmos. Environ., 42, 927939, 2008.

Lyman, S. N. and Jaffe, D. A.: Formation and fate of oxidized mercury in the upper troposphere and lower stratosphere, Nature Geosci., 5, 114-117, 2012.

Lynam, M. M. and Keeler, G. J.: Automated speciated mercury measurements in Michigan, Environ. Sci. Technol., 39, 9253 9262, 2005.

Lynam, M. M. and Keeler, G. J.: Source-receptor relationships for atmospheric mercury in urban Detroit, Michigan, Atmos. Environ., 40, 3144-3155, 2006.

Majewski, G., Czechowski, P. O., Badyda, A. J., and RogulaKozłowska, W.: The Estimation of Total Gaseous Mercury Concentration (TGM) Using Exploratory and Stochastic Methods, Pol. J. Environ. Stud., 22, 759-771, 2013.

Murphy, D. M., Hudson, P. K., Thomson, D. S., Sheridan, P. J., and Wilson, J. C.: Observations of mercury-containing aerosols, Environ. Sci. Technol., 40, 3163-3167, 2006.

Paatero, P. and Tapper, U.: Positive Matrix Factorization: a NonNegative Factor Model with Optimal Utilization of Error Estimates of Data Values, Envirometrics, 5, 111-126, 1994.

Pant, P. and Harrison, R. M.: Critical review of receptor modelling for particulate matter: a case study of India, Atmos. Environ., 49, 1-12, 2012.

Parsons, M. T., McLennan, D., Lapalme, M., Mooney, C., Watt, C., and Mintz, R.: Total Gaseous Mercury Concentration Measurements at Fort McMurray, Alberta, Canada, Atmosphere, 4, 472 493, 2013.

Peterson, C., Gustin, M., and Lyman, S.: Atmospheric mercury concentrations and speciation measured from 2004 to 2007 in Reno, Nevada, USA, Atmos. Environ., 43, 4646-4654, 2009.

Pirrone, N., Cinnirella, S., Feng, X., Finkelman, R. B., Friedli, H. R., Leaner, J., Mason, R., Mukherjee, A. B., Stracher, G. B., Streets, D. G., and Telmer, K.: Global mercury emissions to the atmosphere from anthropogenic and natural sources, Atmos. Chem. Phys., 10, 5951-5964, doi:10.5194/acp-10-59512010, 2010.

Reff, A., Eberly, S. I., and Bhave, P. V.: Receptor modeling of ambient particulate matter data using positive matrix factorization: 
review of existing methods, JAPCA J. Air Waste Ma., 57, 146154, 2007.

Ren, X., Luke, W. T., Kelley, P., Cohen, M., Ngan, F., Artz, R., Walker, J., Brooks, S., Moore, C., Swartzendruber, P., Bauer, D., Remeika, J., Hynes, A., Dibb, J., Rolison, J., Krishnamurthy, N., Landing, W. M., Hecobian, A., Shook, J., and Huey, L. G.: Mercury Speciation at a Coastal Site in the Northern Gulf of Mexico: Results from the Grand Bay Intensive Studies in Summer 2010 and Spring 2011, Atmosphere, 5, 230-251, 2014.

Rolph, G. D.: Real-time Environmental Applications and Display sYstem (READY) Website, NOAA Air Resources Laboratory, College Park, MD, available at: http://www.ready.noaa.gov (last access: 20 February 2015), 2014.

Rutter, A. P., Schauer, J. J., Lough, G. C., Snyder, D. C., Kolb, C. J., Klooster, S. V., Rudolf, T., Manolopoulos, H., and Olson, M. L.: A comparison of speciated atmospheric mercury at an urban center and an upwind rural location, J. Environ. Monitor., 10, 102-108, 2007.

Rutter, A. P., Snyder, D. C., Stone, E. A., Schauer, J. J., GonzalezAbraham, R., Molina, L. T., Márquez, C., Cárdenas, B., and de Foy, B.: In situ measurements of speciated atmospheric mercury and the identification of source regions in the Mexico City Metropolitan Area, Atmos. Chem. Phys., 9, 207-220, doi:10.5194/acp-9-207-2009, 2009.

Schroeder, W. H. and Munthe, J.: Atmospheric mercury - an overview, Atmos. Environ., 32, 809-822, 1998.

Selin, N. E. and Jacob, D. J.: Seasonal and spatial patterns of mercury wet deposition in the United States: Constraints on the contribution from North American anthropogenic sources, Atmos. Environ., 42, 5193-5204, 2008.

Sigler, J. M., Mao, H., and Talbot, R.: Gaseous elemental and reactive mercury in Southern New Hampshire, Atmos. Chem. Phys., 9, 1929-1942, doi:10.5194/acp-9-1929-2009, 2009.

Slemr, F., Weigelt, A., Ebinghaus, R., Brenninkmeijer, C., Baker, A., Schuck, T., Rauthe-Schöch, A., Leedham, E., Hermann, M., van Velthoven, P., Oram, D., O’Sullivan D., Dyroff, C., Zahn, A., and Ziereis, H.: Mercury plumes in the global upper troposphere observed during flights with the CARIBIC Observatory from May 2005 until June 2013, Atmosphere, 5, 342-369, 2014.

Song, Y., Dai, W., Shao, M., Liu, Y., Lu, S., Kuster, W., and Goldan, P.: Comparison of receptor models for source apportionment of volatile organic compounds in Beijing, China, Environ. Pollut., 156, 174-183, 2008.

Sprovieri, F. and Pirrone, N.: Spatial and temporal distribution of atmospheric mercury species over the Adriatic Sea, Environ. Fluid Mech., 8, 117-128, 2008.

Stohl, A.: Trajectory statistics-a new method to establish sourcereceptor relationships of air pollutants and its application to the transport of particulate sulfate in Europe, Atmos. Environ., 30, 579-587, 1996.

Stohl, A.: Computation, accuracy and applications of trajectories-a review and bibliography, Atmos. Environ., 32, 947-966, 1998.

Stohl, A., Forster, C., Frank, A., Seibert, P., and Wotawa, G.: Technical note: The Lagrangian particle dispersion model FLEXPART version 6.2, Atmos. Chem. Phys., 5, 2461-2474, doi:10.5194/acp-5-2461-2005, 2005.

Subir, M., Ariya, P. A., and Dastoor, A. P.: A review of the sources of uncertainties in atmospheric mercury modeling II. Mercury surface and heterogeneous chemistry - A missing link, Atmos. Environ., 46, 1-10, doi:10.1016/j.atmosenv.2011.07.047, 2012.

Swartzendruber, P. C.: The distribution and speciation of mercury in the free troposphere of the Pacific northwest, Doctoral dissertation, University of Washington, Seattle, Washington, USA, 2006.

Swartzendruber, P. C., Jaffe, D. A., Prestbo, E. M., Weiss-Penzias, P., Selin, N. E., Park, R., Jacob, D., Strode, S., and Jaeglé, L.: Observations of reactive gaseous mercury in the free-troposphere at the Mt. Bachelor observatory, J. Geophys. Res., 111, D24301, doi:10.1029/2006JD007415, 2006.

Tauler, R., Viana, M., Querol, X., Alastuey, A., Flight, R. M., Wentzell, P. D., and Hopke, P. K.: Comparison of the results obtained by four receptor modelling methods in aerosol source apportionment studies, Atmos. Environ., 43, 3989-3997, 2009.

Temme, C., Blanchard, P., Steffen, A., Banic, C., Beauchamp, S., Poissant, L., Tordon, R., and Wiens, B.: Trend, seasonal and multivariate analysis study of total gaseous mercury data from the Canadian atmospheric mercury measurement network (CAMNet), Atmos. Environ., 41, 5423-5441, 2007.

Thurston, G. D. and Spengler, J. D.: A quantitative assessment of source contributions to inhalable particulate matter pollution in metropolitan Boston, Atmos. Environ., 19, 9-25, 1985.

Timonen, H., Ambrose, J. L., and Jaffe, D. A.: Oxidation of elemental $\mathrm{Hg}$ in anthropogenic and marine airmasses, Atmos. Chem. Phys., 13, 2827-2836, doi:10.5194/acp-13-2827-2013, 2013

Travnikov, O., Lin, C.-J., Dastoor, A., Bullock, O. R., Hedgecock, I. M., Holmes, C., Ilyin, I., Jaeglé, L., Jung, G., Pan, L., Pongprueksa, P., Ryzhkov, A., Seigneur, C., and Skov, H.: Global and Regional Modelling, in: United Nations Economic Commission for Europe, Hemispheric Transport of Air Pollution 2010, Part B: Mercury, Air Pollution Studies No. 18, edited by: Pirrone, N. and Keating, T., ISSN 1014-4625, United Nations Publication, Geneva, Chap. 4, 97-144, 2010.

USEPA: Technology Transfer Network Clearinghouse for Inventories \& Emissions Factors: SPECIATE Version 4.3, available at: http://www.epa.gov/ttn/chief/software/speciate/index. html\#speciate (last access: 20 February 2015), 2014a.

USEPA: EPA Positive Matrix Factorization (PMF) 5.0 Fundamentals and User Guide, available at: http://www.epa.gov/heasd/ research/pmf.html (last access: 20 February 2015), 2014b.

Viana, M., Kuhlbusch, T. A. J., Querol, X., Alastuey, A., Harrison, R. M., Hopke, P. K., Winiwarter, W., Vallius, M., Szidat, S., Prévôt, A. S. H., Hueglin, C., Bloemen, H., Wåhlin, P., Vecchi, R., Miranda, A. I., Kasper-Giebl, A., Maenhaut, W., and Hitzenberger, R.: Source apportionment of particulate matter in Europe: a review of methods and results, J. Aerosol. Sci., 39, 827-849, 2008a.

Viana, M., Pandolfi, M., Minguillón, M. C., Querol, X., Alastuey, A., Monfort, E., and Celades, I.: Inter-comparison of receptor models for PM source apportionment: case study in an industrial area, Atmos. Environ., 42, 3820-3832, 2008b.

Wan, Q., Feng, X., Lu, J., Zheng, W., Song, X., Han, S., and Xu, H.: Atmospheric mercury in Changbai Mountain area, northeastern China I. The seasonal distribution pattern of total gaseous mercury and its potential sources, Environ. Res., 109, 201-206, 2009a.

Wan, Q., Feng, X., Lu, J., Zheng, W., Song, X., Han, S., and Xu, H.: Atmospheric mercury in Changbai Mountain area, northeastern China II. The distribution of reactive gaseous mercury and par- 
ticulate mercury and mercury deposition fluxes, Environ. Res., 109, 721-727, 2009b.

Wang, Y., Huang, J., Hopke, P. K., Rattigan, O. V., Chalupa, D. C., Utell, M. J., and Holsen, T. M.: Effect of the shutdown of a large coal-fired power plant on ambient mercury species, Chemosphere, 92, 360-367, 2013.

Watson, J. G., Chen, L. W. A., Chow, J. C., Doraiswamy, P., and Lowenthal, D. H.: Source Apportionment: Findings from the U.S. Supersites Program, JAPCA J. Air Waste Ma., 58, 265-288, doi:10.3155/1047-3289.58.2.265, 2008.

Weiss-Penzias, P., Jaffe, D., Swartzendruber, P., Hafner, W., Chand, D., and Prestbo, E.: Quantifying Asian and biomass burning sources of mercury using the $\mathrm{Hg} / \mathrm{CO}$ ratio in pollution plumes observed at the Mount Bachelor Observatory, Atmos. Environ., 41, 4366-4379, 2007.

Weiss-Penzias, P., Gustin, M. S., and Lyman, S. N.: Observations of speciated atmospheric mercury at three sites in Nevada, USA: evidence for a free tropospheric source of reactive gaseous mercury, J. Geophys. Res., 114, D14302, doi:10.1029/2008JD011607, 2009.
Weiss-Penzias, P. S., Gustin, M. S., and Lyman, S. N.: Sources of gaseous oxidized mercury and mercury dry deposition at two southeastern U.S. sites, Atmos. Environ., 45, 4569-4579, doi:10.1016/j.atmosenv.2011.05.069, 2011.

Xu, L., Chen, J., Yang, L., Niu, Z., Tong, L., Yin, L., and Chen, Y.: Characteristics and sources of atmospheric mercury speciation in a coastal city, Xiamen, China, Chemosphere, 119, 530-539, 2015.

$\mathrm{Xu}, \mathrm{X}$. and Akhtar, U. S.: Identification of potential regional sources of atmospheric total gaseous mercury in Windsor, Ontario, Canada using hybrid receptor modeling, Atmos. Chem. Phys., 10, 7073-7083, doi:10.5194/acp-10-7073-2010, 2010.

Xu, X., Akhtar, U., Clark, K., and Wang, X.: Temporal Variability of Atmospheric Total Gaseous Mercury in Windsor, ON, Canada, Atmosphere, 5, 536-556, 2014.

Zhang, L., Vet, R., Wiebe, A., Mihele, C., Sukloff, B., Chan, E., Moran, M. D., and Iqbal, S.: Characterization of the sizesegregated water-soluble inorganic ions at eight Canadian rural sites, Atmos. Chem. Phys., 8, 7133-7151, doi:10.5194/acp-87133-2008, 2008. 